\title{
La escritura y los procesos de occidentalización del mito y legitimación de la imagen en Las Postrimerías de Carabuco ${ }^{1}$
}

por

Sebastián Ferrero

Université de Montréal

Por encargo del cura doctrinero de Carabuco, Joseph de Arellano, el pintor José López de los Ríos realizó hacia 1683 una serie de cuatro lienzos sobre el tema de las Postrimerías en donde se incluyó un ciclo narrativo de treinta escenas representando el paso de un apóstol por los Andes y la historia de la Cruz que habría dejado en Carabuco. Estos episodios fueron presentados al interior de círculos divididos en dos mitades: reservando la parte superior a la representación iconográfica y la inferior a la escritura. Este trabajo pretende reflexionar sobre las interrelaciones icono-textuales que se entablan en los lienzos realizados por José López de los Ríos, demostrando que la inclusión de la escritura, funcionó como agente de occidentalización y legitimación de la representación iconográfica de una historia que encuentra sus orígenes en relatos orales andinos de tiempos inmemoriales.

Palabras clave: Postrimerías Carabuco; José López de los Ríos; Joseph de Arellano; escritura e imagen; oralidad andina.

\section{INTRODUCCIÓN}

Como ya había crecido Jesucristo y era joven y fuerte, quiso ganar a su hermano mayor Inka. « ¿Cómo le ganaré? » decía. A la luna le dio pena. «Yo puedo ayudarte» le dijo, y le hizo caer una hoja con escrituras. Jesús pensó: «Seguro con

\footnotetext{
${ }^{1}$ Una versión sintetizada del presente estudio fue presentado en el marco del XLV Congreso de la Asociación Canadiense de Hispanistas, celebrado entre los días 23 al 26 de mayo del 2009 en la ciudad de Ottawa, Canadá. Es mi deseo agradecer especialmente a los profesores Catherine Poupeney-Hart, Luís de Moura Sobral y a los examinadores externos por sus acertados comentarios, sugestiones y correcciones. Asimismo, mi más sincero agradecimiento hacia el Prof. Lorenzo Pericolo quien posibilitó en gran parte el desarrollo de esta investigación.
} 
esto se va a asustar Inka». En una pampa oscura le enseñó el papel. El Inka se asustó de no entender las escrituras. «¿Qué cosas serán esos dibujos? ¿Qué quiere mi hermanito?» Se corrió, se fue lejos².

Un rápido, pero no menos interesado, repaso sobre el inmenso corpus de pinturas producidas en el virreinato del Perú entre los siglos XVII y XVIII nos deja una sensación inequívoca: artistas e ideólogos coloniales recurrieron sistemáticamente a la letra, a las inscripciones verbales, para incluirlas dentro de los espacios pictóricos de sus realizaciones visuales. Letra e imagen se complementaron, se distanciaron, trabaron animado diálogo dentro de un mismo espacio físico; en otras palabras, formaron parte de un sistema semiótico dinámico y amplio de interrelaciones entre signos convencionales e icónicos.

El gran desafío evangélico que significó América para la Iglesia católica necesitó de la puesta en marcha de ambiciosos programas de enseñanza de los principios y dogmas cristianos a una población neófita en la Fe «verdadera». Para este propósito se acudió a la elaboración de complejos esquemas pedagógicos multisensoriales en donde la imagen y la palabra fueron complementos esenciales en la transmisión de mensajes cristianos. El carácter multicultural del receptor americano demandaba una insistencia particular sobre la correcta «lectura» de una imagen. Desde esta perspectiva, no es difícil entonces entender que la letra funcionara como anclaje de la imagen anulando así la polisemia de los signos icónicos ${ }^{3}$, aunque, claro está, el éxito real de estas dinámicas icono textuales, pensado en términos didácticos, se viera amenazado en la práctica por la falta de conocimiento de gran parte de la masa de las comunidades indígenas de la grafía occidental.

Mientras que la pintura europea de los siglos XVI al XVIII demostraba una marcada tendencia orientada a la creación de imágenes que no dependan de rótulos verbales que explicasen escenas o ciclos narrativos ${ }^{4}$, en la produc-

\footnotetext{
${ }^{2}$ Mito recogido por Alejandro Ortiz Rascaniere del relato de Don Isidro Huamani, natural de la región de Andamarca. Ortiz Rascaniere, 1973: 241. Según Ortiz el relato de Huamani se construye siguiendo el principio dual de la mítica andina, privilegiando un sistema de relaciones de «dioses y hombres, opuestos y antagónicos, ligados uno al día y otro a la noche.» Ibidem: 245. La relación de los hermanos del relato de Huamani, Inka y Jesucristo, se inscribe en este sistema de oposiciones que permite generar el principio de «relación creación-destrucciónfiliación». Ibidem: 249. El caso de la escritura en particular es para Ortiz Rascaniere una de las armas con las que fuera favorecido Jesucristo (a través de la luna) para provocar la destrucción de una primera humanidad (aquella creada por Inka) y construcción de una segunda.

${ }^{3}$ Ver sobre este tema lo concluido por López-Baralt con respecto a la relación icono-textual en la Nueva crónica de Guamán Poma, López-Baralt, 1988: 389-409.

${ }^{4}$ Por otra parte, debe señalarse que para diversos tratadistas y escritores de la Edad Moderna, quienes estuvieran fuertemente influenciados por los antiguos, la inclusión de inscripciones
} 
ción artística colonial el uso de inscripciones al interior de cintas, filacterias o cartelas se hacía cada vez más recurrente, acercándose más, inevitablemente, de la pintura medieval que de su contemporánea europea. Sin embargo, no debe verse en esto un síntoma de arcaísmo o provincialismo, sino más bien el resultado de la evolución pictórica en contextos de realización diferentes, tanto culturales como sociales.

Por otra parte, debemos recordar, como es suficientemente sabido, la fuerte incidencia que ejerció el grabado europeo, principalmente flamenco, sobre la pintura colonial. Esto es pertinente si tomamos en cuenta que muchos de estos grabados contaban con leyendas explicativas y descriptivas que ayudaban al espectador-lector a decorticar correctamente los mensajes, más aún, todos aquellos grabados que formaban parte de Biblias, Breviarios u otros libros ilustrados. A partir de la experiencia y los ejemplos que otorgaban el grabado, artistas, comanditarios e ideólogos de las imágenes coloniales pudieron percibir la relación entre letra e imagen como sistemas complementarios, lo que dificultó por momentos diferenciarlos con claridad ${ }^{5}$. Pareciera cierto, sin embargo, que la transferencia de estos modelos hacia otros soportes materiales (pinturas murales, lienzos o tablas) supuso una reinversión de las fórmulas icono-textuales, ya que, tal como sugiriera Wallis en los libros ilustrados, y a diferencia de las pinturas con inscripciones, the word is not an adjunct to the image, but the image is an adjunct to the word $[\ldots]^{6}$. Por lo tanto, es necesario favorecer nuevas aproximaciones críticas que contemplen los procesos de creación y de recepción de las pinturas con inscripciones ${ }^{7}$.

Si desde lo formal la utilización reiterada de este sistema semiótico dentro de la pintura colonial es hereditaria de tradiciones transatlánticas, ya sean didácticas, medievales o del grabado, estos elementos no son suficientes para explicar las dimensiones, funciones y repercusiones que alcanzó esta interrelación semiótica en el Perú. No debemos perder de vista que la cuestión de la

dentro de espacios pictóricos pudo ser entendida como un artificio comúnmente utilizado por pintores mediocres que no eran capaces de imitar correctamente el mundo natural, teniendo que recurrir a textos que identificaran lo representado. Para un mayor desarrollo de este tema ver Morán Turina, y Portús Pérez, 1997: 117-127.

${ }_{5}$ En este sentido Rappaport y Cummins, entendieron que «it is [...] clear that the division between the written and the pictorial was not always apprehended when European models were copied». Rappaport y Cummins, 2012: 205.

${ }^{6}$ Wallis, 1973: 2.

${ }^{7}$ Debemos también tomar en cuenta que el grabado se desarrolla en un contexto material que es similar al del modelo paradigmático del libro en el siglo XVI, es decir, el papel, la tinta y los mismos procesos de impresión. Mignolo, 1994: 227-228. Aunque la imagen fuese el objeto principal del grabado no podía, desde su aspecto material, desvincularse completamente de la producción escritural. 
escritura en América fue un fenómeno complejo dentro de la agenda colonial y por consiguiente, no sería apropiado estudiar las relaciones entre imagen y letra en la pintura andina fuera de esta coyuntura socio-cultural.

La letra en América ocupó un papel preponderante en la consumación de las conquistas, la consolidación y jerarquización de la sociedad colonial, la apropiación histórica del pasado autóctono y la transmisión de mensajes filosóficos y religiosos occidentales. La escritura fue para el español un arma, una herramienta que autorizaba su accionar, un artefacto que justificaba, sino profesaba, la dominación y control sobre las nuevas posesiones transatlánticas. Así lo entendió Cornejo Polar cuando advirtió que «la escritura en los Andes no es sólo un asunto cultural; es, además, y tal vez sobre todo, un hecho de conquista y dominio» ${ }^{8}$. Más allá de sus funciones significativas, la escritura asumió en América la función de instrumento o de objeto, portador de una carga simbólica tanto política como religiosa, que los europeos se encargaron de alimentar de acuerdo a la tradición gramatológica de Occidente 9 .

Como bien lo había notado Martin Lienhard las primeras acciones perpetuadas por los europeos en América durante la toma de territorios y dominación de las poblaciones indígenas estuvieron apoyadas por la autoridad conferida por un documento escrito, nos referimos ciertamente al Requerimiento ${ }^{10}$. Más allá de que para Sara Castro-Klaren, la confrontación con la escritura, a través del «rito» de la lectura del Requerimiento, no debe haber sido tan novedosa para el nativo americano, ya que los indígenas pudieron haber construido rápidamente lazos de continuidad entre las nuevas prácticas a las que se enfrentaba y sus propias experiencias político-religiosas, la letra y el poder legitimado fueron instituciones íntimamente ligadas desde los inicios e instauración del régimen colonial. Esto permitió a Castro-Klaren suponer que «la engañosa y cínica práctica española de leer el requerimiento desde alta mar a los habitantes de la costa del Caribe, y su posterior manejo de la letra y el poder de la ley, sirvió para recordarles en carne viva a los ciudadanos de este hemisferio el hecho que la escritura y el poder van siempre "en bracelete" $\gg "$.

Probablemente nadie sintió en sus espaldas el poder de la escritura como lo debieron experimentar los andinos en el célebre y nefasto encuentro de Cajamarca entre Atahualpa, el padre dominico Vicente Valverde y las fuerzas

${ }^{8}$ Cornejo Polar, 1994: 39.

9 Rama, 1984: 33.

10 De esta manera Lienhard afirma que «en términos más abstractos la escritura corresponde a la vez a una práctica político-religiosa (la toma de posesión con vistas a su evangelización) y a otra jurídica o notarial (dar fe de las responsabilidades individuales implicadas)». Lienhard, 1991: 5.

${ }^{11}$ Castro-Klaren, 1989: 163-164. 
pizarristas. Como ya se sabe en esa oportunidad el padre Valverde entregó al Inca Atahualpa una Biblia o un breviario argumentando que contenía la palabra del Dios verdadero. Según muchos cronistas presenciales del hecho, el Inca esperó que el libro le hablase, y al no ocurrir esto, Atahualpa, enojado y dando descrédito de la palabra de Valverde, tiró el libro al suelo originando el accionar de los militares españoles. Sin lugar a dudas, fue la primera vez que los andinos sintieron el poder que ejercería la escritura y más precisamente las Santas Escrituras sobre sus comunidades, lo que explica claramente que Sabine Mac Cormack haya definido este hecho como «[...] la primera vez en que muchos andinos fueron sometidos por la autoridad escrita» ${ }^{12}$.

La escritura en América fue mucho más que un sistema de notación, fue, y tal vez sobre todo, un instrumento esencial en la «ritualización» del poder. El valor simbólico que aureoló la letra, transformó la escritura en un componente fundamental de legitimación. De esta manera, las inscripciones al interior de los espacios pictóricos cumplieron una función simbólica particular de acuerdo a los diferentes contextos de realización y recepción de la obra. En términos de legitimación, la letra fue capaz, por ejemplo, de elevar ciertas pinturas al estatus de documentos legales, principalmente aquellas que formaron parte de compendios judiciales ${ }^{13}$; de legitimar la posición social de un individuo dentro del sistema colonial, como los retratos, haciendo de ellos memoriales del poder colonial ${ }^{14}$, de absorber la carga espiritual en las pinturas religiosas favoreciendo la confrontación de los pares dialécticos sustancia/esencia e imagen/escritura; $y$, finalmente, como agente de occidentalización de mitos, capaz de asegurar la inclusión de América dentro de la historia universal de tradición judeo-cristiana.

Es justamente sobre este último punto que centraremos el análisis de este estudio. Buscaremos demostrar que la inclusión de la escritura en los lienzos realizados por José López de los Ríos en la iglesia de Carabuco, fue portadora de una carga simbólica particular, de manera que pudiera funcionar como agente de occidentalización del mito y legitimación de una iconografía novedosa como la Historia de la Cruz de Carabuco y la vida y pasaje de uno de los apóstoles de Cristo por tierras americanas. En otras palabras, mostraremos como, lejos de cumplir solamente la función de esclarecimiento y legibilidad de los episodios representados, la escritura se representaba ella misma como

\footnotetext{
12 Mac Cormack, 1988: 701.

13 Cummins y Rappaport, 1998: 10.

14 Estabridis Cárdenas, 2003, vol. 2.
} 
instrumento de legitimación y de autoridad de una verdad revelada, la venida por vez primera del Evangelio a América ${ }^{15}$.

Hablar de la escritura en tanto agente de occidentalización del mito no supone solamente entenderlo como mecanismo de transformación narrativa que se activa a través de un proceso de reescribir o recrear, sino más bien, entendemos occidentalización como forma de someter al mito a estructuras fundacionales en dónde la historia occidental forja sus bases, siendo la escritura el principal recurso artificioso para lograr estos propósitos. Comprendemos que este concepto podría generar cierta polémica, pero desde aquí no tenemos pretensiones de alimentar este debate ${ }^{16}$.

\section{LA ESCRITURA Y LA LEGITIMACIÓN DE LA HISTORIA Y LA IMAGEN}

Hacia $1683^{17}$ el cura doctrinero de Carabuco Joseph de Arellano encargaba al pintor José López de los Ríos la realización de una serie de cuatro lienzos sobre Las Postrimerías, estos son el Purgatorio (fig. 1), el Juicio final (fig. 2), el Infierno (fig. 3) y la Gloria (fig. 4). Se trataba de una temática que ganó gran popularidad en las iglesias peruanas y altoperuanas. Mucha confianza se tenía en el poder persuasivo que adquirían las escenas escatológicas sobre las

${ }^{15}$ En el IV Encuentro Internacional del Barroco celebrado en la ciudad de La Paz, Gabriela Siracusano llamó la atención sobre la relación particular que se creaba en el lienzos del Infierno de López de los Ríos entre un motivo icónico, «un sinuoso hálito blanquecino», y uno de los textos dispuesto en la parte superior del Infierno, particularmente en el hiato de la palabra CAMINUM (CA / MINUM). Para Siracusano aquí se produce «una asociación palabra-imagen que funciona como un recurso deíctico que señala, marca y orienta nuestra atención». Siracusano, 2007: 116. No trataremos en este estudio lo mencionado por Siracusano, quien, por otra parte, lo hace de forma muy lúcida, simplemente, queríamos advertir sobre las posibilidades críticas que ofrecen las relaciones icono-textuales que decididamente se crean en los lienzos de Carabuco. El caso planteado por Siracusano nos recuerda las propuestas de Claude Gandelman quien entendía que las palabras en las pinturas poseían propiedades «kinéticas», es decir la posibilidad de estas de atraer y dirigir la mirada del espectador hacia puntos y motivos iconográficos precisos del lienzo de manera a favorecer un circuito controlado en la lectura de una obra. Así, Gandelman, sugería que la escritura «imposes movement on the observer even when this observer is supposed to be contemplating a picture dispassionately from a non-moving "point of vision"». Gandelman, 1989: 144. Claro está, en cuanto a lo señalado por Siracusano los «movimientos impuestos» se recrean a través de la comunicación «palabra-imagen» y no sólo por la escritura.

${ }^{16}$ Ver por ejemplo: Walter Mignolo, 1995.

17 Siracusano, 2007: 116. Los lienzos se acabarían en 1684 según la noticia que nos ofrece la cartela, poco tiempo después que Arellano salió de la doctrina de Carabuco. 
Figura 1. José López de los Ríos, Purgatorio, 1684, Óleo sobre tela, Iglesia de Carabuco, Bolivia

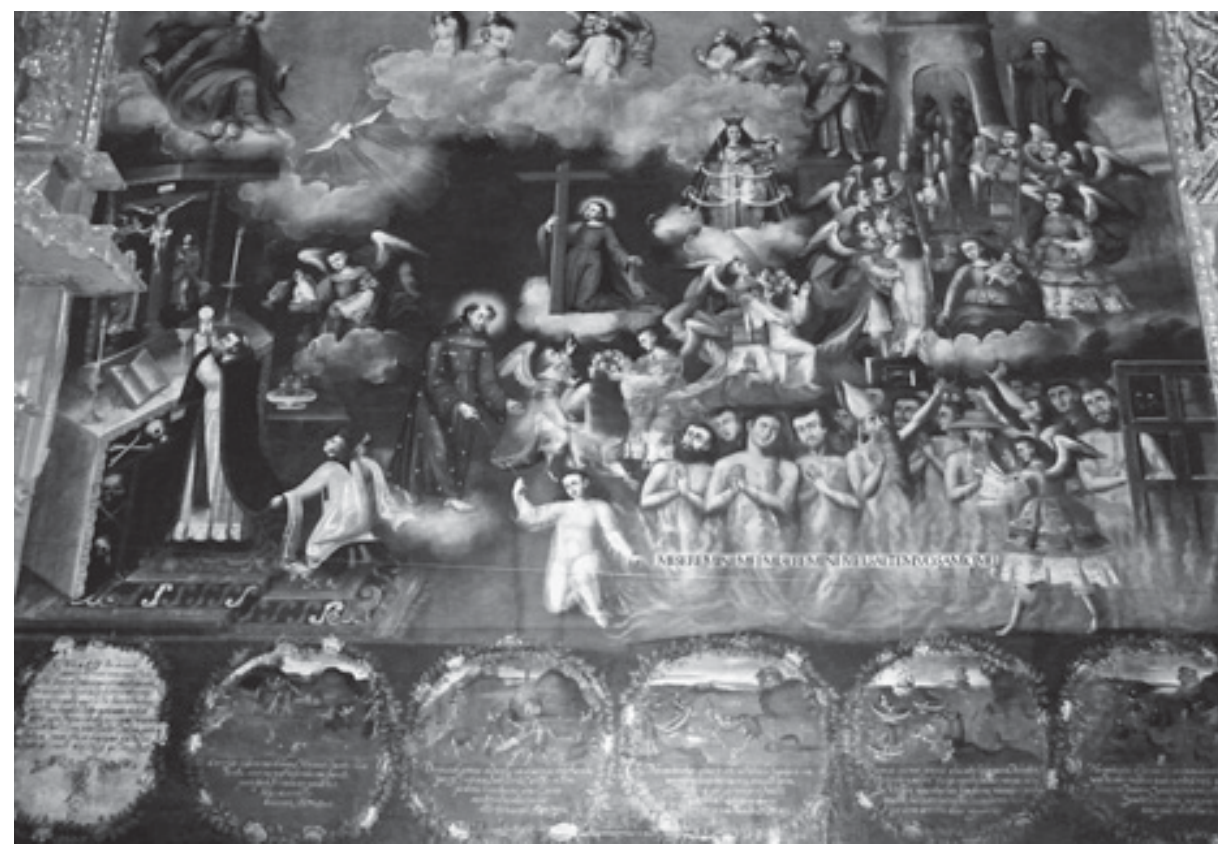

Fotografía: Sebastián Ferrero.

comunidades nativas, así se entiende, como ya lo han notado otros autores ${ }^{18}$, que Guamán Poma se pronunciara enérgicamente a favor de la inclusión de estas representaciones en iglesias y parroquias de indios.

Las Postrimerías de Carabuco contaban con la particularidad de contener en la parte inferior de los lienzos la representación de la historia de la reliquia más importante que se conservara en Carabuco, la Cruz que habría dejado uno de los apóstoles de Cristo (Santo Tomás o San Bartolomé de acuerdo con las diferentes fuentes) en su paso por suelo andino. Se trata de una serie de 30 episodios representados al interior de círculos con orlas florales. Los diez primeros episodios, disponiéndose en la parte inferior de la Gloria y el Purgatorio, fueron consagrados a la narración de la venida del apóstol a tierras andinas. En cuanto a los veinte restantes, ubicados en la parte inferior del Infierno y el Juicio Final, relataban las vicisitudes sufridas por la Cruz, sus intentos de destrucción ordenados por el demonio y los milagros que ella realizó.

${ }_{18}$ Por ejemplo: Mesa y Gisbert, 1982: 91. Stastny, 1994: 14. 
Figura 2. José López de los Ríos, JUicio FINAL, 1684, Óleo sobre tela, Iglesia de CARABuco, Bolivia

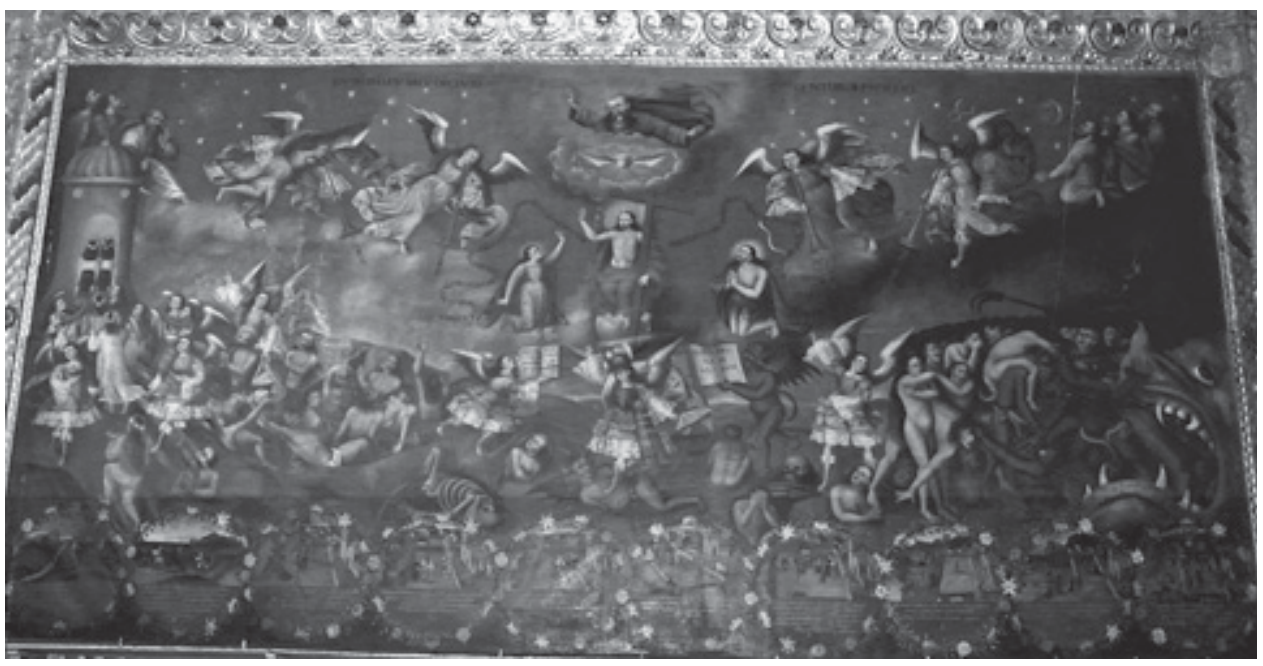

Fotografía: Sebastián Ferrero.

Figura 3. José López de los Ríos, InFierno, 1684, Óleo sobre tela, IgLEsia de CARABUCO, Bolivia

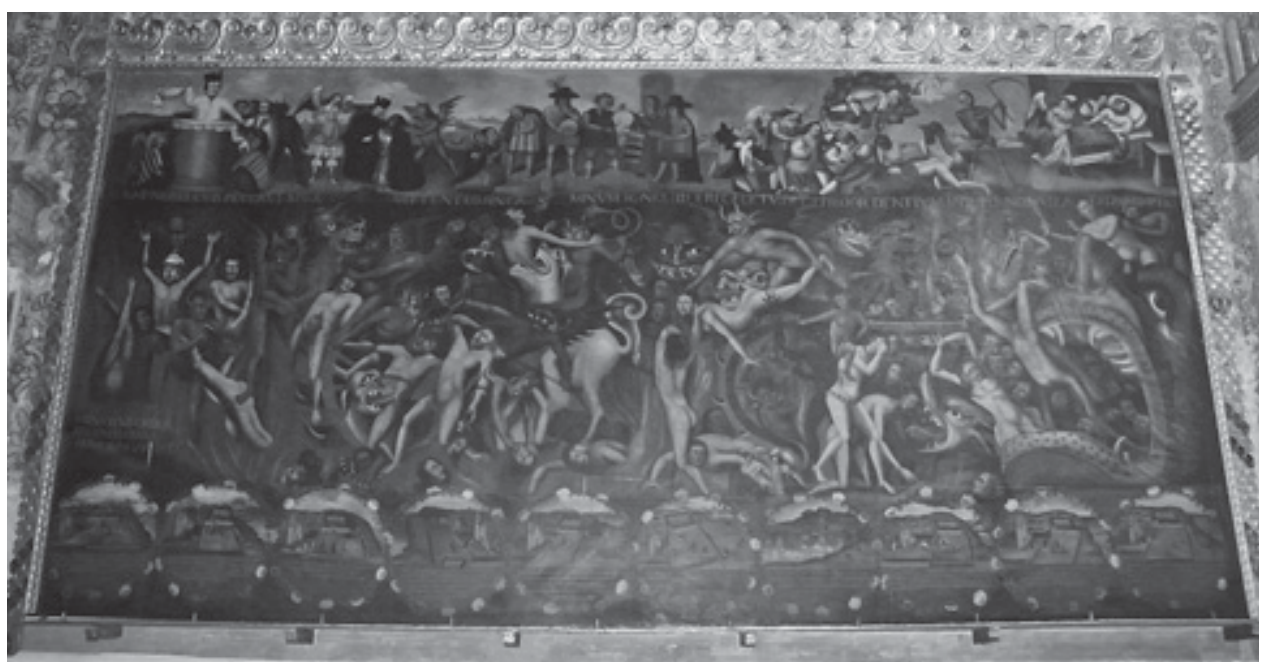

Fotografía: Sebastián Ferrero. 
Figura 4. José López de los Ríos, Gloria, 1684, Óleo sobre tela, Iglesia de Carabuco, Bolivia

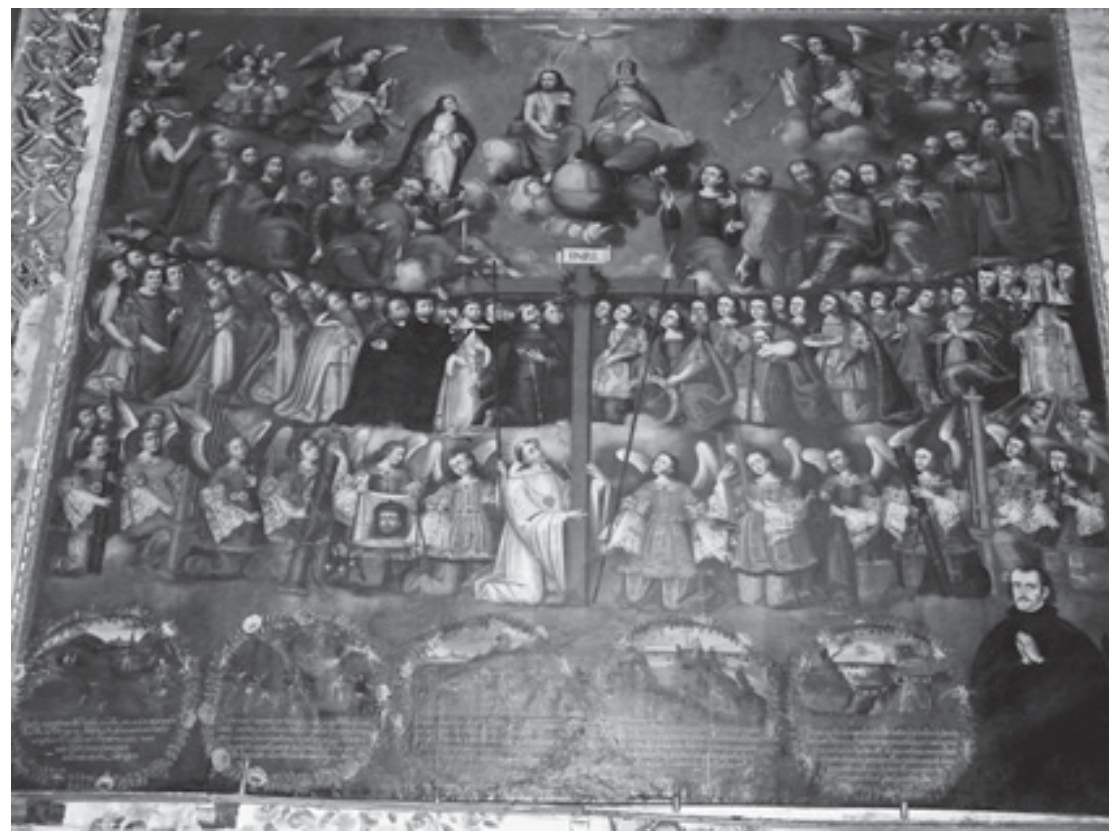

Fotografía: Sebastián Ferrero.

Los principales elementos del contrato del encargo de los lienzos se exponen en una cartela ubicada entre el quinto y sexto episodio de esta historia (fig. 5). En ella se puede leer el nombre de las partes que constituyen el presente contrato: el del mecenas, Joseph de Arellano y el del pintor José López de los Ríos (al cual se le adjunta el título de «maestro», determinando probablemente el estatus alcanzado por el artista), como así también la fecha de finalización de los lienzos (1684), y por consiguiente, del vínculo contractual.

Más allá de estos datos que nos permiten trazar los orígenes de estas obras, la cartela se ocupaba principalmente de destacar la figura de Joseph de Arellano, a quien, por otra parte, se lo retrataba de medio cuerpo en la parte inferior-derecha de la Gloria, junto al primero de los medallones del ciclo narrativo del apóstol en los Andes (fig.6) ${ }^{19}$. La utilización de textos que digni-

19 Se reconoce otros retratos de Arellano en diversos lugares de los lienzos de Carabuco, como por ejemplo, se lo ve junto a otras almas en el Purgatorio o predicando y tomando confesión en la parte superior del Infierno. Tudisco y Guerra, 2010: 69. La multiplicación de 
Figura 5. José López de los Ríos, Purgatorio (Detalle), 1684, óleo sobre tela, Iglesia de Carabuco, Bolivia

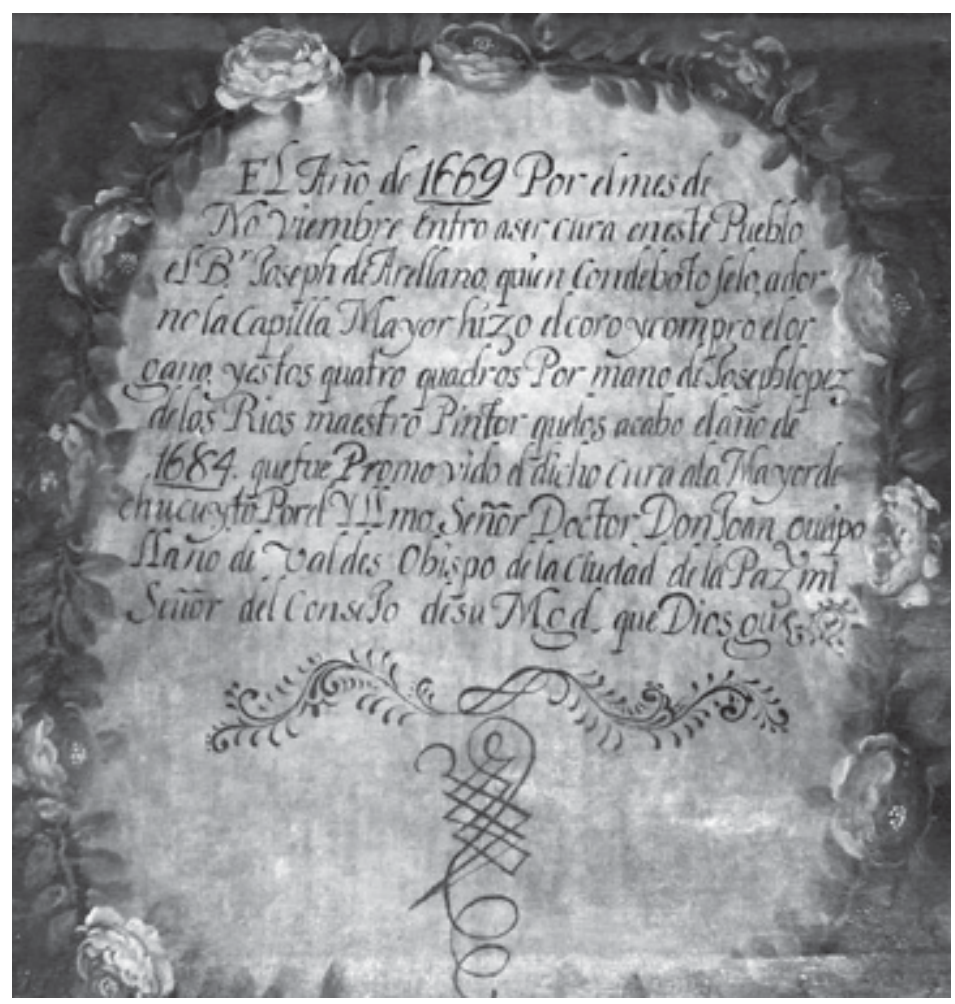

Fotografía: Sebastián Ferrero.

ficaban la figura del personaje retratado era una modalidad dentro del retrato peruano, en donde texto e imagen formaban un todo indisociable constitutivo de los memoriales del poder colonial. Los textos que allí se disponían eran

estos retratos del cura de Carabuco nos muestra la importancia que adquiría Arellano y la gran implicación del mismo en la concepción de la obra. No queremos, sin embargo, ocuparnos exclusivamente sobre el lugar privilegiado que se autoconcede Arellano en los lienzos, sino, más bien, sobre la posición que tomó en referencia a un sujeto controversial como es el de la venida de un apóstol de Cristo a América, y, principalmente, sobre los medios empleados para legitimar su posición y la historia. También, debemos señalar, que el cura de Carabuco participaba como personaje de la narración, más precisamente en diferentes sucesos notables de la Cruz durante el periodo colonial. Así se lo nombra y se lo representa por ejemplo en el episodio 24, donde el cura es testigo de un milagro de resurrección de dos personas muertas en la Iglesia durante trabajos de refacción de la misma. Idem. 
Figura 6. José López de los Ríos, Gloria, Retrato de Joseph de ARellano, 1684, óleo sobre tela, Iglesia de Carabuco, Bolivia

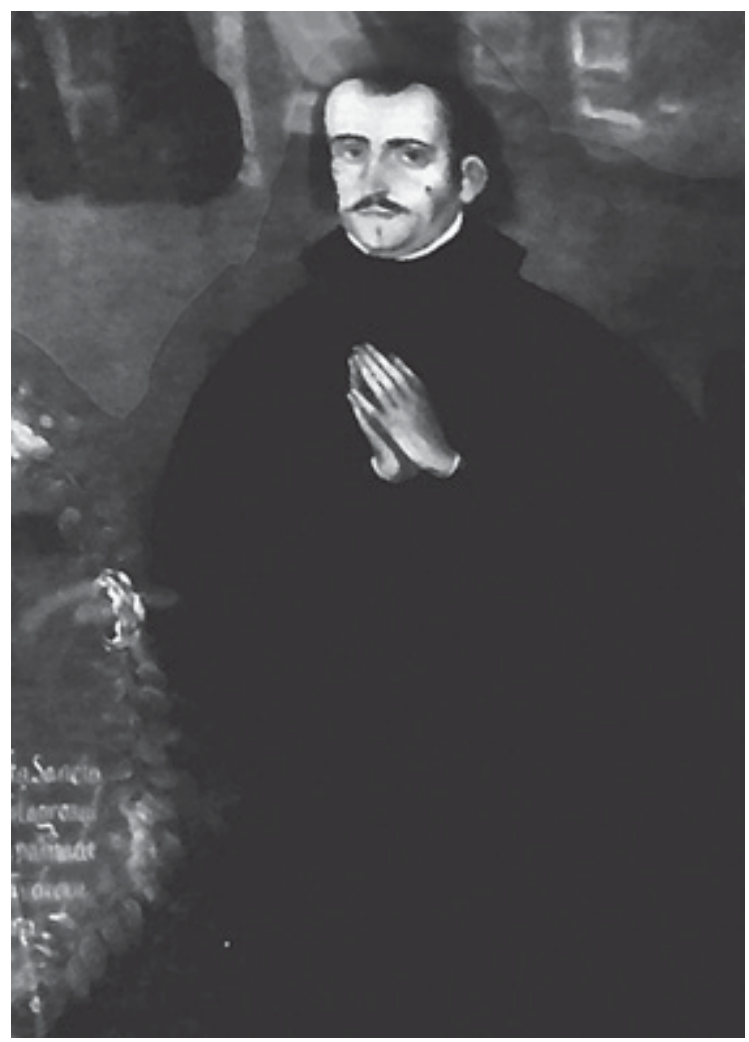

Fotografía: Sebastián Ferrero.

cuidadosamente seleccionados de manera a mostrar los logros sociales, políticos o económicos que posicionaran de la mejor forma al individuo dentro del aparato socio-político de la Colonia. Así, por ejemplo, los criollos incluían en sus retratos una mención sobre puestos alcanzados en la administración pública (puestos, por otro lado, de muy difícil obtención) o uniones matrimoniales que aseguraban el estatus social privilegiado del retratado. De igual manera, las élites políticas hacían gala en las cartelas de asensos que demostraban sus excelentes desempeños dentro de la función pública ${ }^{20}$.

${ }^{20}$ Para un estudio sustancial y detallado del retrato peruano colonial ver Estabridis Cárdenas, 2003, vol. 2: 135-171. En este trabajo Estabridis había notado muy oportunamente la importancia del uso de cartelas dentro de la pintura de retrato, como así también la atención 
El texto de la cartela que figuraba sobre el Purgatorio en Carabuco no escapaba a esta constante. Siguiendo con la retórica propia del retrato virreinal, la cartela desarrollaba con elocuencia las obras devotas realizadas por Arellano para la iglesia y lo que era más importante, una promoción a la Mayor de Chucuito ordenada por el Obispo Juan Queipo Llano de Valdés, puesto que sería ocupado por Arellano tiempo antes que las pinturas fueran concluidas.

La cartela concluye con un motivo que completa el espacio dejado en «blanco», una rúbrica que mostraba una serie de líneas entrecruzadas realizadas de un solo trazo ${ }^{21}$. Las firmas, las rúbricas (motivos floridos) y el signo (una suerte de emblema) son marcas de autentificación a través de las cuales el notario aseguraba la legalidad de lo arriba expuesto ${ }^{22}$. Al mismo tiempo estos elementos alcanzaban carácter de grafías únicas, es decir ellos eran rasgos distintivos de cada notario en particular ${ }^{23}$.

Si bien no existe la presencia de firma y signo en el caso de la cartela de Carabuco, la rúbrica aquí expuesta bien podría tratarse de un motivo «único»

especial que se prestaba en cuanto a la elección de su contenido para remarcar el estatus privilegiado del retratado.

${ }^{21}$ Estas rúbricas derivan de las letras mayúsculas adornadas de motivos caligráficos que encuentran sus orígenes en el trazo florido de de Jean Flamel (c. 1330-1418), secretario del Duque de Berry (1340-1416). El desarrollo hacía motivos de gran complejidad alcanzó sus puntos más notables durante los siglos XVI y XVII, publicándose diversos tratados de arte caligráfico y arte de escribir en donde se enseñaba y se reproducía refinados ejemplos de letras floridas y rúbricas entrelazadas con motivos figurativos. Entre los numerosos ejemplos de maestros calígrafos decisivos en el desarrollo de estos trazos destacamos la obra del más célebre de entre ellos Jan van de Velde (1568-1623) quien publicó en 1605 Spieghel der schrijfkonste alcanzando un gran éxito editorial. No dejamos de nombrar otros maestros como Tomaso Ruinetti (Act. 1619), José de Casanova (1613-1692), Jean de Beaugrand (c.1584-1640) o Edward Cocker (1631-1676).

El arte de la caligrafía era dominado por escribanos y notarios quienes mostraban su destreza realizando ornamentos y rúbricas generalmente en el comienzo y al final de manuscritos y documentos legales. Recordemos lo que sugería José de Casanova en su Primera parte del arte de escrivir todas formas de letras (1650) con respecto al uso de mayúsculas «enlazadas con diferentes bueltas y rasgos». Estas «usan los Maestros - dice Casanova - en los principios de las materias, y al pie dellas donde firman su nombre, para demostrar la destreza de su mano; y también se permite al principio de una Escritura, o carta; pero no en la continuación de los escritos, que sería desproporcionar, y confundir la letra [...]». Casanova, 1650: 15.

22 Burns, 2010: 74-75. En el Tesoro de la lengua castellana de Sebastián de Covarrubias puede leerse que la rúbrica forma parte de la firma haciendo «firme todo lo contenido, y escrito encima de [ella].» Citado por Cummins y Rappaport, 1998: 26.

${ }^{23}$ Como sostuvo Kathryn Burns «The notary's marks were the linchpin of notarial culture, its sine qua non. [In Peru] the boys and adolescents who worked for notaries practiced making their own flourishes over and over. For them, this marked the summit of a career path, the moment when they would not have to write much of anything else». Burns, 2010: 75. 
emparentado a un oficial «plumario» o quizás a un aprendiz ${ }^{24}$. La rúbrica de la cartela del lienzo del Purgatorio, como así también, los ornatos caligráficos introducidos en algunos de los textos de los episodios del apóstol y la Cruz de Carabuco no poseían la calidad y la complejidad de grandes maestros caligráficos europeos como Jan van de Velde (1568-1623), Ruinetti (Act. 1619) o Jean de Beaugrand (c.1584-1640), sin embargo, su ejecutante daba muestras de estar formado en el arte de la escritura, y lo que es más importante legalizaba las aspiraciones, en términos de verosimilitud, del texto.

En lo que concierne a la caligrafía general de los diferentes tondos que narran la historia del apóstol y la Cruz de Carabuco, se trata de una cursiva itálica de buen pulso, una caligrafía muy próxima a la bastarda española de Francisco Lucas (Arte de escribir, 1570). También es de uso correcto en lo concerniente a las abreviaturas del texto, de manera que esto contribuyera a la legibilidad general ${ }^{25}$.

Para muchos autores coloniales era dificultoso pensar que América había quedado fuera del proyecto evangélico del apostolado, por lo tanto, se intentó

${ }^{24}$ Para los esposos Mesa y Gisbert muchos pintores cusqueños estaban relacionados con diversos «oficiales plumarios» o maestros calígrafos. Esta relación era «imprescindible si se tiene en cuenta los extensos letreros que presentan las series de vidas de santos, en los cuales era necesario un oficial que supiera escribir [...] más [aún si se tiene en cuenta que] el pintor como era frecuente no sabía leer ni escribir.» Mesa y Gisbert, 1982: 209. Asimismo, y por lo expuesto hasta aquí, es fácil suponer que el hecho de recurrir a un oficial plumario no resolvía solamente cuestiones prácticas (analfabetismo), sino que a su vez podría injerir en la «firmeza» de los contenidos expuestos. Por otra parte, Mesa y Gisbert revelaban que, en un documento del cobro de un contrato entre el pintor cusqueño Marcos Zapata y por el entonces difunto Pedro de Urra, el oficial plumario Matías de Navia actuó como testigo del contrato. Idem.

${ }^{25}$ Es un punto importante ya que sobre gran parte de eso dependía la calidad del buen calígrafo. Así lo entendía, una vez más, José de Casanova quien advertía: «Una de las partes más principales que los escritos requieren para su bondad, es que la letra sea clara, y legible, porque si esto le falta, aunque cada letra sea un diamante, en no dejándose bien leer, pierde todo su valor [...] En esto pecan muchos, particularmente los Escribanos y sus Oficiales, y hombres de papeles, como claramente se ve en muchas escrituras y procesos, así antiguos, como modernos, tan llenos de abreviaturas hechas con tan poco arte y fundamento, que es necesario interpretar lo que quiere decir». Casanova, 1650: 18.

No deberíamos perder de vista asimismo el valor formal que alcanza la grafía occidental, irrumpiendo decididamente en el terreno de la visualidad «pura». Mucha razón tenía Garín Ortiz de Taranco al sugerir que «la letra vale por sí como obra de arte, aparte de lo que puede significar. [...] las letras, o lo que parece serlo, valen por sí mismas, aparte de su semántica, exista esta o no; las letras no sólo dicen cosas, mediante una 'cognitio obscura' leibnitziana, propia de lo científico y descifrable, sino que valen para intuir belleza, sugerir ritmos y melodías en una 'cognitio distincta' propia de la directa y rápida apreciación estética». Garín Ortiz de Taranco, 1971: 260-61. 
demostrar que el Evangelio había sido difundido en tierras andinas, mucho antes de la conquista, por un apóstol comúnmente asociado a San Bartolomé o Santo Tomás, dos apóstoles que habían predicado en las Indias Orientales ${ }^{26}$.

La historia de la venida de un apóstol a los Andes se entremezclaba con tradiciones orales andinas, las cuales fueron recopiladas por diversos cronistas coloniales. Según se desprende de estos relatos, en tiempos inmemoriales un hombre blanco, barbado y de ojos azules habría estado predicando en estas tierras, realizando diferentes portentos. En los Andes esta deidad se la conoció y veneró bajo el nombre de Tunupa, Taguapaca o Tarapaca, una divinidad que en la mayor parte de los relatos se encuentra asociada al agua, al trueno y al fuego. Concordamos con Théresse Bouysse-Cassagne cuando sostiene que el grado de cristianización con que se relata el mito desde las fuentes coloniales (la autora llama principalmente la atención en la influencia de la literatura hagiográfica en la construcción del mito de Tunupa) hace prácticamente imposible recomponer por completo la estructura mítica del relato ${ }^{27}$. A pesar de ello, es indudable que la historia de la venida del apóstol se alimentó de componentes surgidos directamente de la tradición oral, y que en este caso se podría remontar, como sostuvo Nathan Wachtel, a sustratos pre-aymaras (uru), reestructurándose sucesivamente por aymaras e incas ${ }^{28}$. De todos modos, Santo Tomás o San Bartolomé y Tunupa quedaron en los tiempos coloniales confinados a un mismo espacio en donde convergen diferentes dinámicas socio-culturales.

Todos los episodios que relataban el paso del apóstol por los Andes y la historia de la Cruz dejada en Carabuco fueron representados en tondos decorados con orlas floreales y divididos casi en dos mitades, reservando la parte superior a la representación visual y la parte inferior a la escritura. Los textos aquí expuestos se basaban en la crónica conventual del fraile agustino Alonso Ramos Gavilán: Historia del Santuario de Nuestra Señora de Copacabana publicada en $1621^{29}$. No se trataba de una copia fiel de la obra de Ramos, el autor de los textos de Carabuco incitado de una gran imaginación pía, esclarece y ofrece nuevos datos sobre la historia del Santo. De forma que, por ejemplo, la bella joven del texto de Ramos se convertía en la Virgen María, como así también, se identificaba al cerro Quilima como

${ }^{26}$ Pease, 1999: 31.

27 Bouysse-Cassagne, 1997.

28 Ver: Wachtel, 1989.

29 Gisbert, 2004: 43. Bouysse-Cassagne sugiere que el informe elaborado por los jesuitas que evangelizaron en Omasuyo, encabezados por el Obispo de Chuquiabo Alonso Ramírez de Vergara, a principios del siglo XVII, habría servido de modelo de la Crónica de Ramos. Bouysse-Cassagne, 1997: 181-182. 
lugar específico donde el diablo encontraba refugio y alentaba la práctica de ritos idolátricos ${ }^{30}$. Asimismo, Arellano continuó la historia hasta los años de su curato, participando de alguno de los milagros que aún se observaban en esta iglesia. Esto último denota el objetivo que perseguía Arellano con estas pinturas: que el verdadero relato histórico trascienda al tiempo; y esta continuidad temporal quedaba de manifiesto en el extenso periodo que cubrían los episodios de Carabuco ${ }^{31}$.

La obra de Ramos Gavilán se manifestaba ineluctable en los lienzos de Carabuco $^{32}$, aunque al final, la referencia que aparecía en el episodio 30 del ciclo iconográfico era otro agustino, el cual se pronunció abiertamente a favor de la existencia de una primera evangelización americana en tiempos del apostolado, nos referimos ciertamente al padre Antonio de la Calancha. En la última frase de los textos de Carabuco y cerrando así el ciclo iconográfico, se lee: «como dice Calancha». Este elemento nos muestra cómo el texto de Carabuco no se limitó a narrar los episodios de manera «instructiva» o «evocadora», sino que al adjuntarse una referencia literal de máxima autoridad, se buscaba legitimar la historia.

Por medio de la utilización de la primera persona, la leyenda que acompaña el primer episodio de la venida del apóstol a Carabuco (fig. 7) comenzaba siendo la voz del autor, Joseph de Arellano: «Porque en silencio no queden los portentos que ha obrado esta santa reliquia determinó mi devoción poner en círculos cortos milagros algunos y entrada del apóstol a este pueblo según noticias [...]». Arellano hacía mención a la utilización de "círculos cortos» para llevar a cabo su propósito, incluyendo entonces los dos sistemas semióticos dentro de un todo constitutivo de la representación de la historia (representación icónica, en lo que respecta el semicírculo superior y signos convencionales en cuanto al semicírculo inferior).

Más allá de ello, Arellano era consciente que el texto allí introducido no se limitaría solamente a auxiliar la imagen, asumiendo así las funciones de anclaje (evitando la polisemia del signo icónico) o relevo (adjuntando información que la imagen es incapaz de suministrar), sino, por el contrario, ganaría un lugar preponderante, transformándose probablemente en el motivo más importante responsable de la pervivencia de la historia. Es decir, a pesar de

${ }^{30}$ Gisbert, 2004: 45.

${ }^{31}$ Estos elementos contemporáneos que incorpora Arellano buscan dar plena vigencia milagrosa a la iglesia de Carabuco. De esta manera se podía atraer fieles y pelegrinos, como se hacía en otros centros importantes de peregrinación (Copacabana, Pomata, Cocharcas, etc.).

32 Teresa Gisbert estudió comparativamente los textos del padre agustino con los textos de las pinturas, estableciendo y esclareciendo así las diferencias entre uno y otro. Gisbert, 2004: 43-46. 
Figura 7. José López de los Ríos, Gloria, PRIMER EPISODIO DE LA VENIDA DEL Santo, 1684, óleo sobre tela, Iglesia de Carabuco, Bolivia

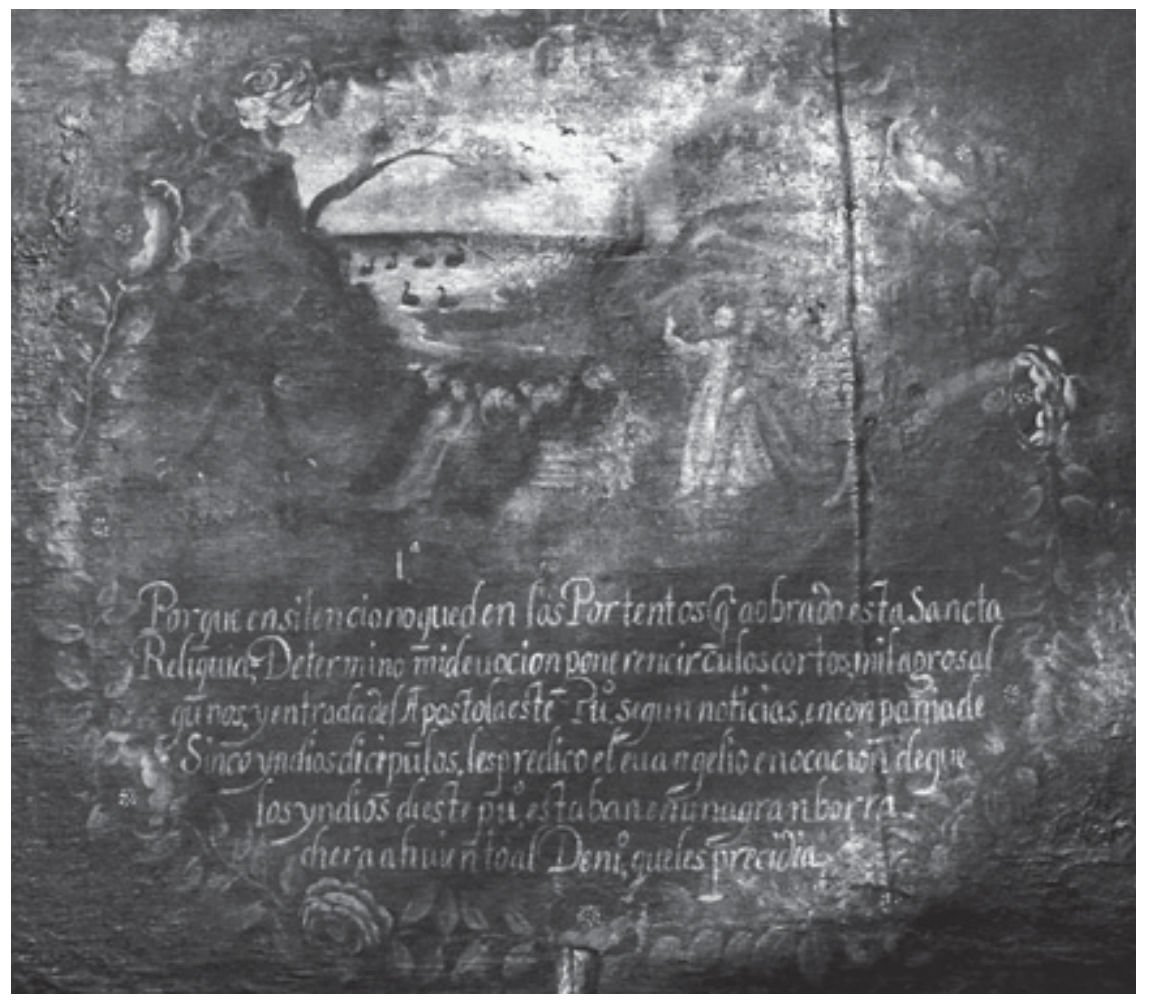

Fotografía: Sebastián Ferrero.

que la imagen y el texto seguían conjuntamente la misma narración histórica de los diferentes eventos, éstas se presentaban como entidades claramente identificables con su propia carga ideológica y simbólica. Al fin de cuentas, es a través de la escritura que la voz de Arellano permite escucharse, esa primera persona revelada a través del posesivo «mi» provocaba la ruptura del silencio en la historia y del carácter silencioso de la pintura.

Si bien es cierto que muchos cronistas entendieron y consideraron la imagen y algunos otros sistemas «alternativos» de escritura prehispánicos (tales como quipus o tocapus en el área andina) como métodos de conservación de la memoria, nadie podía pensar la conservación de la historia sin un sistema alfabético que la preservara. Incluso José de Acosta quien habiendo jerarquizado diferentes sistemas de «notación» (tradicional y alternativos), pero sin 
dejar de considerar todos ellos como eficaces métodos mnemotécnicos ${ }^{33}$, no entendía «cómo - por ejemplo- los aztecas podían tener historia si no tienen escritura, que la escritura alfabética es una sofisticación tecnológica de las formas de conservar el pasado en tanto que la conservación del pasado es esencial al ser humano como lo es el habla» ${ }^{34}$.

No deberíamos ir muy lejos y recordar que la fuente primera de los textos de Carabuco, el agustino Ramos Gavilán, había dejado bien claro en el capítulo XI de su Historia de Copacabana la postura que tomaba el Occidente en relación a la estructura dialéctica, escritura/historia. De esta manera, Ramos argumentaba:

La falta que los indios han tenido de letras y caracteres ha hecho lastimoso estrago en los acaecimientos de su antigüedad [...] Y la tradición es corta en los Naturales, como también lo fuera en todas las naciones del mundo a faltarles la escritura. [...] Concedo que cual y cual suceso notable podrá transferirse de unas en otras memorias; y así juzgo que la venida de nuestro Santo a estos Reynos y Provincias de las Indias Occidentales, fue misterioso en la opinión de los Indios, porque al menos que siendo en el crédito de ellos admirable y de estruendo, no quedara tan firme su noticia ${ }^{35}$.

Es lógico suponer que el pensamiento de Arellano funcionara bajo estos mismos parámetros, acordando entonces a la letra un valor fundamental como medio de conservación y legitimación de la historia.

Por medio de la escritura y por el poder y autoridad que ella confería, la «historia» occidental se apropió de la historia y la memoria prehispánica. Realizando una simple operación de jerarquías (superioridad de la escritura a la oralidad), el europeo se consideró autorizado a ofrecer una historia mucho más verídica sobre América ya que ella se apoyaba sobre pruebas irrefutables (pruebas escritas). No debemos olvidar que, como bien había destacado Martin Lienhard, «desde la edad media, con el prestigio creciente de la escritura y el desarrollo de un verdadero "fetichismo de la escritura", el testimonio oral deja de tener valor, a menos de aparecer consignado en el papel y certificado por un notario» ${ }^{36}$. Recordemos además, que en el capítulo décimo de su Historia, Ramos Gavilán revelaba el modus operandi de legitimación de un testimonio o una tradición oral, un pasaje que no sólo refuerza lo sugerido por Lienhard, sino que, y lo que es más importante para nosotros, nos advierte que las «no-

\footnotetext{
${ }^{33}$ Acosta, 2008 [1590]: 208-211.

${ }^{34}$ Mignolo, 1988: 35.

35 Ramos Gavilán, 1976 [1621]: 39.

${ }^{36}$ Lienhard, 1991: 7.
} 
ticias» a las que refiere Arellano en su texto ya habían sido legitimadas por una suerte de retórica notarial:

Por los años de mil y seiscientos un Corregidor con celo y pecho Cristiano, deseoso de que se declarasen por extenso las cosas de aquel Santo, hizo parecer ante sí un Cacique de Carabuco llamado Don Fernando, el cual según el aspecto y dicho de los que le conocían, fue juzgado por hombre de edad de ciento y veinte años, y sacándolo el corregidor de su pueblo, lo llevó al de los Ancoraymes donde ya con blandura, ya con rigor le pedía declarse [sic] todo lo que a sus antepasados había oído, tocante al Santo, cuya era la Cruz de Carabuco, «confesó por escrito» [... $]^{37}$. (énfasis nuestro)

Thomas Cummins y Joanne Rappaport nos recuerdan que tanto la grafía como el sistema figurativo europeo se insertaron en América de forma simultánea ${ }^{38}$, sin embargo, las comunidades andinas favorecieron el segundo por sobre la escritura, adoptándolo como medio privilegiado de representación de mitos e historias prehispánicas, es decir, como instrumento válido de conservación de sus memorias y continuación de sus propias experiencias culturales ${ }^{39}$. Desde esta perspectiva, las imágenes se emparentaban más a las tradiciones orales que a discursos escritos, conclusión a la que arribaba, por otra parte, y a través del estudio de los dibujos de la Nueva Crónica y buen Gobierno de Guamán Poma, Roberto Viereck, reconociendo, entre otras cosas, «un tipo de pensamiento holístico» que comparten la imagen con la oralidad ${ }^{40}$.

Más allá de lo que se desprende de las propuestas de Viereck y Cummins sobre la relación que establece la oralidad y la imagen, la primera sistémica y la segunda compartiendo rasgos culturales, la aproximación entre estos dos sistemas de comunicación se apoya a partir de su ineficacia para la conservación de la historia.

37 Ramos Gavilán, 1976 [1621]: 36.

${ }^{38}$ Cummins y Rappaport, 1998: 8-9.

39 Ver Cummins, 1998: 91-148.

40 Según Viereck, los dibujos de la Nueva Crónica asumían el rol de la oralidad andina, ocupando «una posición central y dominante» en la obra de Guamán Poma. En lo que concierne a la relación entre imagen y oralidad, Viereck asegura que: «[...] es importante señalar que la visualidad icónica comparte con la oralidad un tipo de pensamiento holístico, en oposición al lógico-analítico que caracteriza esencialmente a la escritura. Así, aún cuando las imágenes y el texto evidentemente interactúan y resulta muy esquemático identificar hemisferios cerebrales con habilidades cognitivas en forma mecánica, pues los procesos cerebrales tienden a ser integrales, sí parece posible impulsar, de cualquier modo, la idea de que los dibujos pueden ser interpretados como sucedáneos simbólicos de una oralidad primaria amenazada por la irrupción violenta de la escritura alfabética durante la conquista [...]». Viereck, 2009: 37. 
De la venida del apóstol se conservaban noticias de tres maneras diferentes. La primera por medio de la oralidad sobre la cual no se construía la historia sino más bien el mito. La ineficacia de la tradición oral ya estaba bien demostrada en el episodio de la venida del apóstol a América. En la misma línea que Ramos Gavilán, Antonio de la Calancha afirma también que: «la falta de las letras, o la sobra de los tiempos aze lastimosos estragos en la certeza de los acaecimientos, i en la integridad de las antiguedades $\gg{ }^{41}$. El paso del tiempo $y$ el desconocimiento de la escritura fueron factores fundamentales para que la historia se corrompa.

La segunda forma de noticia fue por medio de imágenes. El apóstol dejo grabado sobre piedras y losas la huella de sus pies y hasta su cuerpo entero, como si se tratara de un imago maiorum ${ }^{42}$, y pintó sobre la losa, como aquella que se encontró en Calango, una serie de símbolos (llaves y ancla) que Calancha interpretó siguiendo la tradición iconográfica occidental ${ }^{43}$. Todas estas imágenes fueron luego veneradas por indios idólatras. Además de las improntas, Calancha menciona el caso de las representaciones de hombres y niños crucificados encontradas en los primeros años de la conquista en un adoratorio de indios próximo a Quito, las cuales compartían el mismo espacio con otros ídolos paganos ${ }^{44}$. Si bien estas imágenes, de tradición iconográfica cristiana, probaban para Calancha que un hombre de Cristo había pasado por estas tierras, demuestran a su vez que la imagen, aunque posea orígenes cristianos, podía usarse con fines erróneos, siendo incapaz de conservar la verdad del mensaje evangélico con el paso del tiempo, y en ello fracasó tanto como la oralidad.

La tercera manera de conservación de la noticia de la venida del apóstol fue por medio de la escritura. Los religiosos que se encargaron de revisar las reliquias dejadas por el Santo aseguran que en determinados casos, el apóstol escribió con su dedo un mensaje evangélico junto a sus improntas. Lamentablemente, nada de esto, como pudo averiguar Calancha, sobrevivió a las campañas de extirpación de la idolatría ${ }^{45}$. Curiosamente, antes que los

${ }^{41}$ Calancha, 1639: 333-334.

${ }^{42}$ En Calancha, se percibe esta analogía cuando compara las losas y piedras como «cera» o «blanda cera». Ibidem: 326, 329 y 332. Cabe señalar que autores clásicos, como Platón en el Teeteto, utilizaron esta idea de impresión en la cera como metáfora de la memoria.

${ }^{43}$ Las llaves representaban a Pedro y el ancla la esperanza. Según Calancha, estos símbolos podían traducir un mensaje profético de la parte del apóstol, asegurando que «esperasen, que en los venideros tiempos entrarian las llaves de la Iglesia de San Pedro en estas tierras». Ibidem: 328.

44 Ibidem: 329.

45 «El año de mil seycientos i veynte i cinco, me dicen que el Licenciado Duarte Fernandez Visitador del Arçobispo, mandò picar las letras, no puedo creer cosa tan mala». Ibidem: 327. 
textos fueran destruidos, nadie fue capaz de descifrar su contenido ya que no se encontró en los Andes ¡ninguna persona que conozca el griego y el hebreo! Calancha defiende el contexto de la tradición oral como un lugar propicio para la indagación de los sucesos históricos, sin embargo no puede desentenderse del principal argumento de otros religiosos detractores basado en la inexistencia de escritos que probaran la venida de un apóstol a América. Los textos que dejó el Santo mostraban por el contrario que la escritura había participado de la primera evangelización de América y fue el canal por donde se manifestó la revelación del Verbo y la «ley verdadera». Esto último queda evidenciado en el siguiente pasaje de Calancha haciéndose eco de la información propiciada por Fray Raymundo Urtado, padre doctrinero de Calango: «las letras las escribiò con el dedo, dandoles a entender [a los indios], i para comprovar, que el Dios a quien predicava era poderoso i su ley verdadera ${ }^{46}$. Lo narrado por Calancha nos muestra como la letra fue en este caso un artefacto de poder (manifestado a través del milagro, «escribiò con el dedo») y de autoridad religiosa, probando que el apóstol predicaba la Fe verdadera. Es decir, la escritura cumplió el mismo rol que el breviario de Valverde en el encuentro de Cajamarca. Si bien la torpeza de la destrucción de estos textos impidió esclarecer los eventos históricos, la presencia de letras sobre estas imágenes favorecía una reapropiación cristiana del objeto de veneración, que hasta el momento formaba parte del culto pagano.

En Carabuco, las representaciones visuales de la historia del Santo y la Cruz servían ciertamente a fijar en la memoria del espectador imágenes cristianas. El elemento más importante que proporciona la imagen, dentro de esta lógica de construcción de la memoria, es el de poder «visualizar» la historia del Santo en un contexto espacial conocido. De esta manera se ve al apóstol en un paisaje del altiplano, evangelizando indios a orillas del lago Titicaca y combatiendo al demonio que se refugia en el cerro Quilima. Sin embargo, la fijación de una imagen no es más que el primer paso para alcanzar una memoria verdadera, pero no es suficiente. La imagen fija sensaciones pero no transmite el sentido, para ello es necesario someterlas al conocimiento. Es justamente sobre este aspecto que las pinturas de Carabuco podían fracasar. El significado de la imagen dependía del conocimiento del receptor que, en el caso del indígena, podía apoyarse en sus propias tradiciones orales. Dicho de otro modo, el ciclo iconográfico de la Cruz y el Santo de Carabuco lograba preservar tradiciones orales prehispánicas si el receptor se lo propusiese. La escritura podía ser un artificio válido que permite a la memoria, propia del

\footnotetext{
${ }^{46}$ Idem.
} 
universo de la imagen y por consecuencia de los sentidos externos, alcanzar el «verdadero» conocimiento, una suerte de memoria razonada.

El destinatario principal de estas pinturas fue un público indígena, feligreses iletrados que acudían a la doctrina de Carabuco. La relación que estableció este grupo con estos textos debió ser tanto pedagógica como simbólica. Más allá del denotado analfabetismo característico en las doctrinas de indios, los textos de las pinturas de López de los Ríos pudieron revelarse a través de un interlocutor ocasional (siguiendo la tradición europea de la lectura de libros en voz alta para un público iletrado $)^{47}$, o por medio de la palabra oral, al ser incluidos dentro de la temática de pláticas y sermones. Esto no sería extraño ya que las imágenes religiosas en los Andes rara vez fueron autosuficientes. Constantemente formaron parte de redes multisemióticas, en donde la palabra, ya sea ésta escrita o como forma oral ${ }^{48}$ (en este caso por medio de sermones o pláticas) aportaron los conocimientos «verdaderos» que dieran sentido a la imagen.

A pesar de ello, la confrontación de un espectador analfabeto con los textos de Carabuco, sin contar con la ayuda de intermediarios ni traductores, se produjo irremediablemente. Es aquí que la escritura funcionó como representación simbólica o como signo visual de legitimación de la historia. Desprovisto de valor lingüístico, la presencia de textos dentro de este ciclo iconográfico, fue una prueba visual de autoridad y recordaba al espectador que sus tradiciones orales habían sido conquistadas por una «historia verdadera» (una historia escrita).

En consecuencia, podemos entender que los textos en el ciclo de Carabuco no explican solamente las imágenes, sino que también las autorizan, ya sea por medio de la revelación de un conocimiento verdadero como por medio de su representación visual que legitima la historia. Es decir, se proclama que las imágenes son el resultado de la representación visual de una fuente escrita (en este caso el texto de Ramos Gavilán, de forma implícita, y la Crónica Moralizada de Calancha, de manera explícita) y no de una tradición de conservación oral. Una fuente escrita que a su vez se apoyaba en otra fuente de máxima autoridad, las Santas Escrituras. Recordemos que, como bien sugiere Salles-Reese, Ramos Gavilán, por medio de su escrito, «intentó fijar un relato cristiano que se conservaba en la memoria de los indígenas. La escritura forma parte de un intento pragmático concreto de evangelización y dominación» ${ }^{49}$.

47 López-Baralt, 1988: 482.

${ }^{48}$ Nos referimos por supuesto a una oralidad que se encuentra en relación estrecha con la escritura, es decir, una oralidad practicada por sociedades que poseen un conocimiento de la escritura. Para Walter Ong se trataría lo que él llama una oralidad secundaria. Ong, 2006: 20.

49 Salles-Reese, 2008: 141. 
El poder que poseía la letra por sobre la imagen, en cuanto símbolo de autoridad de una verdad, se manifestaba también en términos teologales. Es suficientemente sabido el carácter sagrado que se le acordó a la escritura desde el Medioevo, más aún, como nos recuerda López-Baralt, a partir de que el evangelio de San Juan identificara a Cristo con el Verbo ${ }^{50}$. Es por eso que las relaciones que se articulan entre imágenes y escritura dentro de los espacios pictóricos implica necesariamente la conformación de estructuras dialécticas que equiparen estos dos modelos de representación. Facundo Thomas entendía que se podría establecer un vínculo válido entre el par dialéctico espiritualidad/ materialidad -o el Verbo y la carne- con el par dialéctico escritura/imagen, «siendo cada uno de esos pares el espejo del otro e influyéndose dialécticamente, de manera que las soluciones que se van imponiendo en el terreno de la producción de imágenes influyen las posiciones que se adoptan respecto a las relaciones entre materia y espíritu y viceversa $\rangle^{51}$. En otras palabras, la imagen representa entonces la sustancia (material y visible) en tanto que la escritura es la esencia (espiritual e invisible). Desde este punto de vista, y por dicotomía semántica, la inserción de escrituras reforzaba aún más la condición material de la imagen al mismo tiempo que insistía sobre la esencia espiritual de la letra. De cierta manera, las inscripciones al interior de una pintura argumentaban la utilización de la imagen, advirtiendo al espectador que la esencia espiritual sobrepasaba los terrenos materiales de la representación visual, la cual no debía ser venerada por sí misma, para alojarse en una suerte de verdad metafísica de la letra.

Ciertamente, el poder civilizador de la letra, ya sea en términos culturalesideológicos o simbólico-religiosos, alcanzaba para legitimar y «occidentalizar» una tradición prehispánica. Empero, en estos lienzos la escritura debía también autorizar, uno de los elementos más originales que aportaba Arellano sobre la historia del apóstol en tierras andinas y la Cruz de Carabuco: la iconografía. La utilización de la escritura como forma de legitimación, a partir de su carácter civilizador, permitiría a estas escenas forman parte de la tradición iconográfica de occidente.

Aquí, nos parece interesante referir a lo propuesto por Marianna Lora en su estudio de las representaciones en torno a la doctrina de la Inmaculada Concepción luego que se animara calurosamente el debate una vez oficializada la doctrina por el papa Sixto IV hacia la década de $1480^{52}$. Esto nos permite entender la idiosincrasia occidental en lo que respecta a

\footnotetext{
50 López-Baralt, 1988: 408.

51 Tomás, 1998: 31.

52 Lora, 2007: 240.
} 
la jerarquización entre imagen y escritura, y los mecanismos puestos en marcha para «oficializar» un modelo iconográfico. Marianna Lora había notado que estas obras, impulsadas por inmaculistas (particularmente franciscanos) contaban con la inclusión de carteles y filacterias que referían principalmente a la condición inmaculada de la Virgen María. Más allá de que las diversas leyendas aportaran claridad a un tema de muy difícil representación, Lora sostiene que la escritura en este caso, también era consecuencia de la «necesidad de legitimar una doctrina que había sido fuertemente criticada, [las inscripciones en los lienzos] pretenden encausar la doctrina bajo argumentos de la patrística y la teología» ${ }^{53}$. (traducción nuestra). Lo propuesto por Lora nos permite entender mejor el mecanismo puesto en marcha en Carabuco y el esfuerzo de Arellano para legitimar una iconografía de un tema muy problemático por medio del poder que aureola la escritura en el pensamiento occidental.

Por otro lado, lo representado en Carabuco, como en el caso que nos plantea Lora, podía provocar algún debate (aunque en los tiempos de Arellano se había apaciguado considerablemente) y requería de autoridades que legitimaran nuevos modelos iconográficos. En este contexto, Arellano se permite imaginar e idealizar un público (espectador y lector) diferente a los feligreses de la doctrina, un público corporativo cristiano, conformado por hombres y autoridades de letras, con el cual Arellano entabla el debate, definiéndose a su vez como parte integrante de este universo letrado.

San Bernardo de Claraval ¿nuevos espacios de diálogo en Carabuco?

Las pretensiones de que un apóstol de Cristo había recorrido el suelo americano, evangelizando y predicando en tiempos inmemoriales, contó con sus detractores dentro del clero, tanto secular como regular y mendicante. Es decir, no todos compartieron el entusiasmo de los padres agustinos Antonio de la Calancha y Alonso Ramos Gavilán.

Agustinos y jesuitas fueron probablemente los que más insistieron en los beneficios que ofrecía, en pos de la evangelización de las comunidades indígenas, la transformación de creencias locales a «sanos» principios y dogmas católicos, y estas transformaciones alcanzaban, sin duda, las decisiones adoptadas en el terreno del imaginario colonial. Sin embargo, esto no aseguraba que los mitos prehispánicos que ellos mismos cristianizaban pudieran finalmente

\footnotetext{
${ }^{53}$ Ibidem: 242.
} 
formar parte de la historia universal de tradición cristológica ${ }^{54}$. Más allá de ello, este caso particular concerniente a la venida de un apóstol al Nuevo Mundo enfrentó las posturas de agustinos y jesuitas quienes al parecer no compartieron el mismo punto de vista sobre esta cuestión ${ }^{55}$.

Así, fueron muchos los opositores a las hipótesis que pretendían ver una primera evangelización de América antes de la llegada de los españoles ${ }^{56}$. El más importante de entre ellos, de una lista que incluía cronistas tales como Arriaga, Sahagún y Albornoz, fue, probablemente, el padre jesuita José de Acosta ${ }^{57}$. Para este autor, cualquier similitud entre leyendas, ritos y ceremonias prehispánicas con las Santas Escrituras, dogmas y cultos cristianos no era más que una reproducción del Diablo de los modelos históricos de la cristiandad, con el fin de consumar en la tierra su reino de la herejía. En su Historia Natural y Moral de las Indias (1590), Acosta aseguraba:

[...] se ha de advertir una cosa que es muy digna de ponderar: y es que como el demonio ha tomado - por su soberbia, bando y competencia con Dios - lo que nuestro Dios con su sabiduría ordena para su culto y honra, y para bien y salud del hombre, procura el demonio imitarlo y pervertirlo para ser él honrado y el hombre más condenado. Y así vemos que - como el Sumo Dios tiene sacrificios y

${ }^{54}$ En lo que concierne directamente a la presencia de un apóstol de Cristo en territorio americano, Sanfuentes aseguraba que la certeza de la venida del Evangelio a América mucho antes de la instauración del régimen colonial, justificaba, de manera profética, el accionar de los europeos en el Nuevo Mundo. Sanfuentes, 2003: 188. Dicho de otro modo, la misión europea en América era la de recordar las enseñanzas del apóstol que habían degenerado hacia cultos idolátricos con el paso de los siglos.

${ }_{55}$ Estenssoro argumenta que a partir de la dimensión que alcanzó este tema en las primeras décadas del siglo XVII, los jesuitas se vieron obligados a aceptar los componentes evangélicos en torno a la leyenda, sin embargo no buscaron concederle valores salvacionistas, sino más bien, destacar las conductas idolátricas e impías de los indios en tiempos que el Santo evangelizaba el Nuevo Mundo. Estenssoro Fuchs, 2005: 149-152.

56 Juan Carlos Estenssoro nos recuerda asimismo que el virrey Francisco de Toledo mandó se destruyeran todas las reliquias que se le atribuyeron al apóstol en su paso por suelo americano. Sin embargo, Calancha, como hemos visto, sitúa la destrucción de muchas de ellas en tiempos postoledanos. Ibidem: 149.

${ }_{57}$ Remarcamos, por otra parte, que Salles-Reese insiste sobre el origen criollo de los principales impulsadores de la leyenda, estos son los padres agustinos Antonio de la Calancha y Alonso Ramos Gavilán, y en contrapartida, el origen español de sus opositores, como el jesuita José de Acosta. Para esta autora, el apoyo de los criollos hacia las hipótesis de la primera evangelización americana antes del descubrimiento, denotaba el deseo de este sector social de incluir América dentro de la historia universal de tradición judeocristiana. Salles-Reese, 2008: 148. Esto se asemeja, claro está, al orgullo criollo manifestado a santos americanos, como Santo Toribio Mogrovejo y Santa Rosa de Lima, los cuales se transformaron en estandartes de una identidad americana naciente. 
sacerdotes y sacramentos, y religiosos y profetas y gente dedicada a su divino culto y ceremonias santas - así también el demonio tiene sus sacrificios y sacerdotes y su modo de sacramentos, y gente dedicada a recogimiento y santimonia fingida, y mil género de profetas falsos ${ }^{58}$.

Según se desprende de esta última cita, para Acosta Tunupa, podía asemejarse más a un «santo fingido» o a un «falso profeta» del demonio que al apóstol de Cristo, ya sea identificado como Santo Tomás o San Bartolomé.

Demás está decir la posición que tomó Arellano, favoreciendo claramente las ideas impulsadas por los agustinos. Muy probablemente, en los tiempos de Arellano la controversia, que se acaloró durante las últimas décadas del siglo XVI y las primeras del XVII, había naturalmente apaciguado. Sin embargo, podía dejar el peor de los resultados contra el cual luchaba Arellano: el silencio o el olvido. Si fue un apóstol el que transitó el continente americano, silenciarlo sería desacreditar la obra del apostolado y el mandato de Cristo.

Más allá de las intenciones de Arellano de dejar testimonio de la historia, podríamos preguntarnos si en los lienzos de Carabuco, el cura intentó contribuir en este debate con nuevos argumentos y espacios de reflexión. Esto último nos lleva a prestar una atención singular sobre un detalle en el lienzo de la Gloria.

Al centro de este lienzo, entre un conglomerado de mártires, santos, apóstoles y evangelistas se destaca claramente la representación de San Bernardo (fig. 4). Flanqueado por ángeles músicos y por otros que portan los instrumentos de la pasión, el cisterciense ocupa un lugar dominante con respecto al resto de los santos fundadores y principales de las órdenes religiosas que aparecen representados en el registro inmediatamente superior.

Dentro de la tradición iconográfica occidental, la representación de San Bernardo rodeado de los diferentes instrumentos de la pasión de Cristo (Cruz, martillo y clavos, corona de espinas, columna de la flagelación, etc.) tiene suficiente asidero. Así lo advierte José de Almonacid en su Vida al «[...] dar razon de muchas pinturas, que se avran visto de mi Glorioso San Bernardo en que le ponen [...] abrazado con los instrumentos de la Passion de Nuestro Redemptor [...] $\rangle^{59}$. Este modelo iconográfico circuló por medio de grabados, que fueron probablemente conocidos en América, como por ejemplo un grabado de Cornelis Cort (publicado por Lorenzo Vaccari en 1576) y otro de Hieronymus Wierix (ant. 1619). En ambos casos se representó a San Bernardo llevando entre sus brazos una suerte de improvisado «ramillete» con los diferentes instrumentos de la pasión presionados contra su pecho. Asimismo,

\footnotetext{
58 Acosta, 2008 [1590]: 167.

59 Almonacid, 1682: 585.
} 
además de los instrumentos de la pasión, se adjunta en estos grabados el estandarte de los cruzados, recordando el comando militar y espiritual de San Bernardo en la segunda cruzada de 1145.

Si bien la asociación entre San Bernardo y los instrumentos del martirio de Cristo estaba ampliamente sostenida desde la tradición iconográfica europea, no es común que el misticismo bernardino simbolizado a través de estas representaciones, tomara tal importancia en las visiones de la Gloria o la Corte celestial como la que se pintó en Carabuco.

Andrés de Mesa y Teresa Gisbert demostraron que existían dos obras de similar factura a las de Carabuco, una de ellas una pintura mural en la Iglesia Ispahán (1640-1655, Irán) y la otra un lienzo de autor anónimo en la Iglesia de Santa María (Ledesma, Salamanca) representando las Postrimerías. A partir de este hallazgo, se concluyó entonces que un mismo grabado había servido de modelo para estas tres obras ${ }^{60}$. Dicho grabado fue hallado por Gabriela Siracusano en el Kunsthistorisches Institut de Florencia en colaboración con su director el Prof. Dr. Gerhard Wolf ${ }^{61}$. Debe notarse que de todas estas representaciones, ya sean las pinturas o el grabado que sirvió de fuente visual, la única que muestra a San Bernardo al centro de la Gloria en compañía de la Cruz, es el lienzo de Carabuco. Tampoco ocupa la posición central en Cortes celestiales más tardías que se encuentran en otras iglesias andinas. Nos referimos por ejemplo al Juicio Final de la Iglesia de Caquiaviri (Anónimo, 1739) y a los murales de Tadeo de Escalante en Huaro (1804), que presentan también similitudes con el gravado del Kunsthistorisches Institut ${ }^{62}$. En general la Cruz es transportada por ángeles o en su defecto por San Francisco (apoyado en la identificación del santo de Asís con Cristo al ser el primer santo en recibir los estigmas) pero la presencia de San Bernardo es novedosa.

Ante la rareza de esta elección, nos parece válido preguntarnos si no había otras razones que incentivaron este gesto. No podemos pasar por alto que en Carabuco la representación de la Cruz adquiere un poder simbólico particular a causa de tratarse del verdadero leitmotiv del ciclo iconográfico y desde aquí la figura del cisterciense puede ganar en importancia. A través de este motivo se crean lazos visuales entre el santo cisterciense y el apóstol que recorrió América, como si se pudiera ver en San Bernardo una suerte de su alter ego. Del mismo modo puede notarse que en la iglesia, el lienzo de la Gloria está ubicado frente al Purgatorio, confrontando así, al centro de ambas composiciones, a San Bernardo con el apóstol «americano», ambos sosteniendo la Cruz.

\footnotetext{
60 Mesa y Gisbert, 2011: 16-19.

61 Siracusano, 2011: 111.

62 Idem.
} 
En mi opinión, existen dos elementos en la vida de San Bernardo que pudieron haber motivado esta elección tan particular. Por un lado uno histórico que tiene que ver con la condición de cruzado de Bernardo, rasgo fundamental de su vida, que ciertamente no podía desconocer Arellano, y otro epistemológico que recuerda la importancia de la exegética en la doctrina bernardina.

Por mandato del papa Eugenio III, Bernardo se puso al frente de la segunda cruzada de 1145, cumpliendo un rol de máxima importancia como orador y predicador, convenciendo primero a señores y monarcas europeos sobre los beneficios de esta empresa, y luego predicando el evangelio y marchando al frente de la misión hacia Tierra Santa. Solamente el papel de evangelizador que desempeño Bernardo bastaría para comprender la presencia destacada de Bernardo en Carabuco, más aún, si tomamos en cuenta que la campaña de Bernardo pudo haber sido entendida por aquellos tiempos, como una campaña con fines escatológicos ${ }^{63}$. Sin embargo, son los resultados y las consecuencias desastrosas de esta segunda cruzada lo que transformaba a Bernardo en una suerte de alter ego del apóstol de los Andes, y lo que llamaba a los incrédulos a realizar una reflexión profunda de su postura.

Como bien sabemos luego del fracaso rotundo de esta empresa, las máximas autoridades políticas y religiosas arremetieron contra Bernardo, acusándolo directamente de ser el responsable de semejante desastre. A decir verdad, la empresa entera de la segunda cruzada fue demonizada, viéndose en ella la mismísima obra del anticristo, y Bernardo, como principal mentor de esta campaña, absorbió lo peor de las críticas. Por ejemplo, y tal como nos recuerda Miethke, «un cronista de Wurtzbourg entendió la derrota de la armada cristiana una prueba que Dios se permitió para su Iglesia a causa de sus pecados. Solamente falsos profetas, hijos del demonio, verdaderas cabezas del Anticristo habían podido conducir a los cristianos, a través de argumentos insensatos, a liberar Jerusalén» ${ }^{64}$. (traducción nuestra).

En su Vie de S. Bernard de 1649, Antoine Le Maistre dedicaba el capítulo XIII del cuarto libro a la controversia que se genero en torno de la figura de San Bernardo, luego del fracaso de la empresa santa de 1145. Así puede leerse:

Empero, la humildad y la paciencia de nuestro Santo aparecieron en respuesta a las calumnias que aquellos, que no consideraron más que los eventos externos y temporales de las más santas empresas, propinaron contra él [San Bernardo] de todos

${ }^{63}$ El halo escatológico que pudo haber tenido la Segunda Cruzada fue motivo de opiniones dispares aún en nuestros días. Kahl, por ejemplo, sostenía la hipótesis sobre los fines escatológicos de esta empresa militar y religiosa, en tanto Miethke disentía abiertamente viendo en la Segunda Cruzada una campaña netamente defensiva. Miethke, 1992: 487-488.

${ }^{64}$ Ibidem: 496. 
lados, como si se tratara de un «falso profeta» que había engañado tanto a Príncipes como al pueblo, conduciéndolos hacia Tierra Santa a través de las predicaciones que hizo en Francia y en Alemania ${ }^{65}$. (traducción y énfasis nuestros) (Le Maistre 396).

Y más adelante, Le Maistre sostiene:

Ya que los hombres groseros y carnales no pudieron comprender como podía ser que Dios haya ordenado esta empresa, considerando que ésta había sido tan lamentable para los cristianos, mejor prefirieron creer que no provenía de Dios Padre y que «el Santo no fue más que un falso Profeta» ${ }^{66}$. (traducción y énfasis nuestros) (399).

Entre las innumerables acusaciones que recibió San Bernardo, las más fuertes que debió soportar como vemos fueron aquellas que lo emparentaban directamente a la obra del demonio, considerándolo, finalmente, como un falso profeta. Esto explica la insistencia de Antoine Le Maistre sobre este epíteto y que el Obispo Otón de Freising, cronista del siglo XII, reivindique al Cisterciense como «Oráculo divino: quien fue «Profeta y Apóstol» para los Pueblos de Alemania y Francia» ${ }^{67}$. (énfasis nuestro).

Estos elementos nos permiten establecer lazos entre este periodo de la vida del San Bernardo y la historia de la venida del apóstol a América. El fracaso evangélico fue similar de uno y otro lado y gran parte de las élites religiosas y políticas se preocuparon, claro está, bajo circunstancias diferentes, de demonizar y acusar de falso profeta tanto a Bernardo como al discípulo de Cristo que evangelizó el Nuevo Mundo.

La presencia destacada de San Bernardo en el lienzo de Carabuco funcionaba como referencia histórica y, de algún modo, literal - como veremos más adelante - para llevar la controversia hacia otros terrenos de discusión. Al menos, se intentaba crear argumentos comparativos diacrónicos donde se apelara al uso de máximas autoridades de la historia de la Institución Eclesiástica para reconsiderar la posición que tomaría la Iglesia sobre esta cuestión. Recordemos también que, como bien notó Marianna Lora en su estudio que hemos estado examinando, además de legitimar las imágenes por medio de escritos sobre los lienzos y tablas, se utilizó, a través de su representación pictórica, a personajes de primer orden de la patrística cristiana, fuesen o no los autores materiales de las leyendas allí incluidas ${ }^{68}$. Este es el rol que cumple Bernardo en los

\footnotetext{
${ }^{65}$ Le Maistre, 1649: 396.

66 Ibidem: 399.

${ }^{67}$ Del Corral, 1782: 285.

${ }^{68}$ Lora, 2007: 253-254.
} 
lienzos de Carabuco. Si las fuentes primeras de los textos que acompañan los episodios del Apóstol en los Andes y la historia de la Cruz de Carabuco, es decir los agustinos Ramos Gavilán y Antonio de la Calancha recibían críticas sobre la correcta interpretación exegética de las Santas Escrituras, con Bernardo se accedía a otra instancia de diálogo en la disputa, aunque poco tuviera que ver el cisterciense directamente en lo que concierne a la venida del apóstol a América y, menos aún, en los textos dispuestos en Carabuco.

Asimismo, tanto Ramos, Calancha y ahora Arellano podían compararse a aquellos «más fieles y célebres historiadores del tiempo de Bernardo que inspirados por Dios habían rescatado al Santo de las calumnias, declarando para toda la posteridad cuál había sido la verdadera causa del fracaso de esta empresa [según palabras de Otón de Freising: el orgullo, el libertinaje y los vicios de los hombres] ${ }^{69}$. (traducción nuestra). Es decir, las mismas causas que hicieron fracasar la primera evangelización de América.

No debemos olvidar, por otro lado, que San Bernardo en Carabuco podía funcionar también como una suerte de apoyo metodológico, considerando la importancia que la doctrina bernardina acordaba a la exegética, y que, más allá de una búsqueda seudo-arqueológica de los indicios materiales dejados por el apóstol en América (por ejemplo la Cruz de Carabuco y sus huellas sobre piedras), la prueba fundamental de su presencia se basaba en una relectura de las Santas Escrituras en dónde se revelaba la gracia evangélica que se le acordó a este hemisferio en tiempos inmemoriales ${ }^{70}$.

Notamos, también, que la obra de San Bernardo pudo ser una influencia para Arellano en lo que concierne a la relación entre escritura e imágenes. En el capítulo XII de su Apología a Guillermo de St. Thierry (c.1125), Bernardo se escandalizaba y despotricaba sobre lo que él consideraba un abuso desmedido en lo que respecta la utilización de imágenes, decoración y ornato en las iglesias, reservando hacia el final del escrito una advertencia y crítica hacia los religiosos que preferían «mirar estos mármoles a leer en los manuscritos y pasar así todo el día admirándolos en lugar de meditar sobre la ley de Dios» ${ }^{71}$. (traducción y énfasis nuestros). Cierto es, que en un contexto muy diferente

${ }^{69}$ Le Maistre, 1649: 400.

${ }^{70}$ Ramos acudía a Isaías y a Moisés en el Deuteronomio, para comparar los apóstoles con las nubes y las lluvias que riegan todas las partes del mundo con su palabra, al apóstol San Pablo quien «prueba haber sonado la voz Evangélica en toda la tierra», y a otras fuentes patrísticas y de las Santas Escrituras. Ramos, 1976 [1621]: 27-32.

${ }^{71}$ En este caso en particular Bernardo dirigía su crítica hacía la producción de imágenes fantásticas características del Bestiario medieval, las cuales adornaban los templos, y lo que era más escandaloso los interiores de los conventos y monasterios. Sin embargo debe notarse que el arte religioso no se salvaba de la crítica de Bernardo, quien lo consideraba como una 
al tiempo medieval de Bernardo, en América, y sintiendo los aromas de la política contrarreformista, no se podía prescindir del valor de las imágenes, al menos como primera etapa en la construcción de la memoria. Sin embargo, la jerarquía estaba bien definida, la escritura, en términos de legitimación y de autoridad, venía ciertamente muy por encima de la imagen. Arellano podía fácilmente reconocer que la historia no tendría el mismo sustento siendo únicamente representada por intermedio de la imagen sin apoyarse al menos «visualmente» en textos que la legitimaran.

Por otra parte, San Bernardo hizo de la escritura su acto de devoción y piedad como también lo hiciera Arellano en Carabuco. Las primeras palabras que dieron inicio a la vida literaria de San Bernardo, el prefacio de In Laudibus Virginis Matris (c. 1120), el cisterciense comenzaba de la siguiente manera: Scribere me aliquid et devotio iubet [...] (Escribir, me lo manda / determina la devoción). «¿No es revelador -se preguntaba retóricamente Jean Leclercq- que la primera palabra de la primera obra de San Bernardo sea el verbo escribir?»> ${ }^{72}$. (traducción nuestra). Ciertamente lo es. Arellano comenzaba su texto de una manera muy similar a la frase que da inicio al primer escrito en la obra de San Bernardo: «[...] determinó mi devoción poner en círculos cortos [...]», se lee en Carabuco. Si bien el verbo escribir no está presente en el texto de Arellano, sino más bien un verbo mucho más subjetivo como «poner», no se puede dudar que la injerencia principal y la voz del cura en estas pinturas se manifestaron a través del texto, lo que fuera finalmente su mayor acto de devoción.

\section{CONCLUSIÓN}

Los europeos trasladaron sus propias experiencias, supersticiones y tradiciones con respecto a la escritura para continuarlas en América. El poder que aureolaba a la letra no se ponía en duda en el seno de la sociedad occidental desde el medio evo hasta la era moderna, ya que, como bien lo había notado Walter Mignolo, «el presupuesto de que la cultura y la civilización se fundan, en gran medida, sobre el conocimiento y empleo de la escritura alfabética estaba ya tan arraigado en el siglo XVI que "naturalmente" se daba por sentado» ${ }^{73}$.

práctica muy cercana a la idolatría que requería de costos innecesarios y casi obscenos. San Bernardo, Apología, XII.

${ }^{72}$ Leclercq, 1992: 529.

73 Mignolo, 1988: 36. 
Esta realidad supone la utilización de mecanismos de interpretación que nos permita entender la relación icono-textual a partir de la identificación de estos dos sistemas como entidades generalizadoras, con sus propias cargas simbólicas, de forma que los vínculos entre uno y otro no se hicieran por medio de la descripción, sino a través de la relación dialéctica entre imagen y escritura. Bajo estas premisas, entendemos la inserción de la escritura en las pinturas que hemos estado analizando como una forma de legitimación de discursos orales y representaciones visuales.

En Carabuco, la escritura se presenta como una marca visual del aparato colonizador y como espacio fundamental desde donde se articula y autoriza el conocimiento, elemento fundamental para la construcción de la memoria verdadera. Los textos aquí expuestos rompían un doble silencio: el de la pintura y el de la historia.

Desde su contenido lingüístico y simbólico, la inserción de rótulos en las pinturas de Carabuco ayuda a occidentalizar la tradición oral prehispánica para incluirla dentro de una historia universal, historia esencialmente escrita, que se iniciaba a partir de los orígenes monogenistas de la humanidad y concluía en el Juicio Final.

\section{BiBLIOGRAFÍA}

Acosta, José de, Historia natural y moral de las Indias [1590], Fermín del Pino Díaz, (ed. y estudio preliminar), Madrid, CSIC, 2008.

Almonacid, José de, Vida y milagros del glorioso padre y doctor Melifluo S. Bernardo, Madrid, Francisco Sanz, impresor del Reyno y portero de camara de su magestad, 1682.

Bouysse-Cassagne, Thérèse, "Evangelización, hagiografía y mitos: de Empedocles a Tunupa", Thérèse Bouysse-Cassagne (ed.), Saberes y Memorias en los Andes, Lima, IHEAL-IFEA, 1997: 157-212.

Burns, Kathryn, Into the archive. Writing and Power in Colonial Peru, Durham/ London, Duke University Press, 2010.

Calancha, Antonio de la, Coronica moralizada del Orden de San Augustin en el Peru: con sucesos egenplares vistos en esta Monarquia, Barcelona, P. Lacavalleria, 1639.

Casanova, José de, Primera parte del arte de escrivir todas formas de letras, Madrid, Diego Díaz de la Carrera, 1650.

Castro-Klaren, Sara, Escritura, sujeto y transgresión en la literatura latinoamericana, México, Premia, 1989. 
Cornejo Polar, Antonio, "El comienzo de la heterogeneidad en las literaturas andinas: voz y letra en el 'diálogo' de Cajamarca", Antonio Cornejo Polar, Escribir en el aire. Ensayo sobre la heterogeneidad socio-cultural en las literaturas andinas, Lima, Ed. Horizonte, 1994: 25-89.

Corral, Fray Eugenio del, Vida y milagros del Dulce Doctor y Padre de la Iglesia San Bernardo, Abad de Claraval [...], Madrid, Don Isidoro de Hernández Pacheco, 1782.

Cummins, Thomas, "Let Me See! Reading Is for Them: Colonial Andean Images and Objects "como es costumbre tener los caciques Señores", Elizabeth Hill Boone y Thomas Cummins, (eds.), Native Traditions in the Postconquest World, Washington, D.C., Dumbarton Oaks Research Library and Collection, 1998: 91-148.

Cummins, Thomas and Rappaport, Joanne, "Between Images and Writing: The Ritual of the King's Quillca", Colonial Latin American Review, VII/1 (New York, 1998): 7-26.

Estabridis Cárdenas, Ricardo, "El retrato del siglo XVIII en Lima como símbolo de poder", Ramón Mújica Pinilla (ed.), El barroco peruano, Vol. 2, Lima, Banco de Crédito del Perú, 2003: 135-171.

Estenssoro Fuchs, Juan Carlos, "Construyendo la memoria: la figura del inca y el reino del Perú, de la conquista a Tupac Amaru II", Thomas Cummins et al. (eds.), Los incas, reyes del Perú, Lima, Banco de Crédito del Perú, 2005: 93-173.

Gandelman, Claude, "By Way of Introduction: Inscriptions as Subversion", "Inscription in Painting", Visible Language, XXIII/2-3 (Cincinnati, 1989): 141-169.

Garín Ortiz de Taranco, Felipe María, "Letreros y letroides en la temática artística", Archivo Español de Arte, XIV/175 (Madrid, 1971): 259-282.

Gisbert, Teresa, Iconografia y Mitos Indígenas en el Arte, La Paz, Gisbert \& CIA, 2004.

Gisbert, Teresa y Mesa-Gisbert, Andrés de, "El cielo y el infierno en el mundo virreinal del sur andino", Gabriela Siracusano (ed.), La paleta del espanto. Color y cultura en los cielos e infiernos de la pintura colonial andina, Buenos Aires, Colección Artes y Letras, UNSAM, 2010: 15-32.

Le Maistre, Antoine, La vie de S. Bernard premier abbé de Clairvaux et père de l'Église [...], Paris, A. Vitré et Vve M. Durand, 1649.

Leclercq, Jean, (osb.), "L'écrivain", Bernard de Clairvaux. Histoire, mentalités, spiritualité. CEuvres Complètes), Colloque de Lyon-Cîteaux-Dijon, Paris, Les éditions du cerf, 1992: 529-556.

Lienhard, Martin, La voz y su huella: escritura y conflicto étnico-social en América Latina, 1492-1988, Hanover, N.H., Ediciones del Norte, 1991.

López-Baralt, Mercedes, Icono y conquista: Guamán Poma de Ayala, Madrid, Hyperion, 1988. 
Lora, Marianna, “Quand l'image ne suffit pas. Les inscriptions dans les figurations peintes de l'Immaculée Conception en Italie (Fin du XVe - première moitié du XVI siècle)", Joanna Barreto, et al. (dir.), Visible et lisible. Confrontations et articulations du texte et de l'image, Paris, Nouveau Monde éditions, 2007: 239-270.

Mac Cormack, Sabine, “Atahualpa y el libro", Revista de Indias, XLVIII/184 (Madrid, 1988): 693-713.

Mesa, José de y Gisbert, Teresa, Holguín y la pintura virreinal en Bolivia, La Paz, Librería Editorial Juventud, 1977.

Mesa, José de y Gisbert, Teresa, Historia de la pintura cuzqueña, Lima, Weise, 1982.

Miethke, Jürgen, "L'engagement politique: la seconde croisade", Bernard de Clairvaux. Histoire, mentalités, spiritualité. Cuvres Complètes), Colloque de Lyon-Cîteaux-Dijon, Paris, Les éditions du cerf, 1992: 475-503.

Mignolo, Walter, "Anahuac y sus otros: la cuestión de la letra en el Nuevo Mundo", Revista de crítica literaria latinoamericana, XIV/28 (Hanover, 1988): 29-53.

Mignolo, Walter, "Afterword: Writing and Recorder Knowledge in Colonial and Postcolonial Situations”, Elizabeth Hill Boone y Walter Mignolo (coords.), Writing without words. Alternative Literacies in Mesoamerica and the Andes, Durham and London, Duke University press, 1994: 293-313.

Mignolo, Walter, “Occidentalizacion, imperialismo, globalización: herencias coloniales y teorías postcoloniales", Revista Iberoamericana, LXI/170-71 (Pittsburgh, 1995): 27-40.

Morán Turina, José Miguel y Portús Pérez, Javier, El arte de mirar: La pintura y su público en la España de Velázquez, Madrid, Itsmo, 1997.

Ong, Walter, Oralidad y escritura. Tecnologías de la palabra, Buenos Aires, Fondo de Cultura Económica, 2006.

Ortiz Rascaniere, Alejandro, "El mito de la escuela", Juan Ossio (ed.), Ideología mesiánica del mundo andino, Lima, Edición de Ignacio Prado Pastor, 1973: 237250.

Pease, Franklin, "Temas clásicos en las crónicas peruanas de los siglos XVI y XVII", Teodoro Hampe Martínez (ed.), La tradición clásica en el Perú virreinal, Lima, Universidad Nacional Mayor de San Marcos, 1999: 17-34.

Rama, Ángel, La ciudad letrada, Hanover, Ediciones del Norte, 1984.

Ramos Gavilán, Alonso, Historia de Nuestra Señora de Copacabana [1621], La Paz, Academia Boliviana de la Historia, 1976.

Rappaport, Joanne y Cummins, Thomas, Beyond the Lettered City: Indigenous Literacies in the Andes, Durham/London, Duke University Press, 2012. 
Salles-Reese, Verónica, De Viracocha a la Virgen de Copacabana: representación de lo sagrado en el Lago Titicaca, Lima, Instituto francés de estudios andinos/ Plural, 2008.

San Bernardo, Apologie de saint Bernard adressée à Guillaume de Saint-Thierry, Abbé de Saint-Thierry, www.abbaye-saint-benoit.ch/saints/bernard/tome02/guillaume/ guillaume.htm\#_Toc54096698 (Fecha de verificación: 23 de septiembre de 2015).

Sanfuentes Echeverría, Olaya, "La leyenda de Santo Tomás en América", Memorias del I Encuentro Internacional sobre el Barroco Andino, La Paz, Unión Latina, 2003: 187-201.

Siracusano, Gabriela, "Notas para detener el 'escándalo': Fiesta e idolatría en el Virreinato del Perú", La Fiesta. Memoria del IV encuentro Internacional sobre el Barroco, La Paz, Unión Latina, 2007: 113-122.

Siracusano, Gabriela, La paleta del espanto. Color y cultura en los cielos e infiernos de la pintura colonial andina, Buenos Aires, Colección Artes y Letras, UNSAM, 2010.

Stastny, Francisco, Síntomas medievales en el "Barroco americano", Lima, IEP, 1994. Documento de trabajo 63, Serie Historia del Arte 1.

Tomás, Facundo, Escrito, pintado. Dialéctica entre escritura e imágenes en la conformación del pensamiento europeo, Valencia, Editorial Antonio Machado Libros, 1998.

Tudisco, Gustavo y Guerra, Diego, "El Apóstol soy yo: José de Arellano y el programa iconográfico de la Cruz de Carabuco", Gabriela Siracusano (ed.), La paleta del espanto. Color y cultura en los cielos e infiernos de la pintura colonial andina, Buenos Aires, Colección Artes y Letras, UNSAM, 2010: 55-76.

Viereck, Roberto, "Guamán Poma dibujante o la oralidad como 'lengua traductora", Hipertexto, IX (Texas, 2009): 36-51.

Wachtel, Nathan, "Les transformations de Tunupa. Restructurations religieuses dans les Andes méridionales (XVIe-XVIIe siècles)", Mélanges de l'École française de Rome - Italie et Méditerranée (MEFRIM), 101/2 (Roma, 1989): 839-873.

Wallis, Mieczyslaw, "Inscriptions in Paintings", Semiotica, IX/1 (Toronto, 1973): 1-28.

Fecha de recepción: 9 de julio de 2012.

Fecha de envío de las modificaciones: 19 de agosto de 2013.

Fecha de aceptación: 20 de noviembre de 2013. 


\section{Writing and the Occidentalization Processes of the Myth and the Legitimization of the Image in Carabuco's Last Things}

Commissioned by Joseph de Arellano, parish priest of Carabuco (current Bolivia), the painter José López de los Rios executed a series of four paintings on the theme of the Last Things in 1683. At the bottom of these paintings he included a narrative cycle of thirty scenes depicting the coming of an apostle to the Andes, and the story of the Cross left by said apostle at Carabuco. These episodes were introduced into half-divided circles, reserving the top for the iconography and the bottom for the written word. This work aims to rethink the relationship between images and writing and demonstrate, in this particular case, that the inclusion of writing worked as an agent of legitimization of iconographic representation in order to Occidentalize the oral Andean tradition.

Key words: Last Things Carabuco; José López de los Ríos; Joseph de Arellano; Writing and Image; Andean Oral Tradition. 